\title{
On the spatial distribution and evolution of ultrafine particles in Barcelona
}

\author{
M. Dall'Osto ${ }^{1}$, X. Querol ${ }^{1}$, A. Alastuey ${ }^{1}$, C. O'Dowd ${ }^{2}$, R. M. Harrison ${ }^{3,6}$, J. Wenger ${ }^{4}$, and F. J. Gómez-Moreno ${ }^{5}$ \\ ${ }^{1}$ Institute of Environmental Assessment and Water Research (IDÆA), Consejo Superior de Investigaciones Científicas \\ (CSIC), C/ Jordi Girona 18-26, 08034 Barcelona, Spain \\ ${ }^{2}$ School of Physics, Centre for Climate \& Air Pollution Studies, National University of Ireland Galway, University Road, \\ Galway, Ireland \\ ${ }^{3}$ National Centre for Atmospheric Science, Division of Environmental Health \& Risk Management, School of Geography, \\ Earth \& Environmental Sciences, University of Birmingham, Edgbaston, Birmingham, B15 2TT, UK \\ ${ }^{4}$ Department of Chemistry and Environmental Research Institute, University College, Cork, Ireland \\ ${ }^{5}$ CIEMAT, Environment Department, Av. Complutense 40, 28040 Madrid, Spain \\ ${ }^{6}$ Department of Environmental Sciences/Center of Excellence in Environmental Studies, King Abdulaziz University, Jeddah, \\ 21589, Saudi Arabia
}

Correspondence to: M. Dall’Osto (manuel.dallosto@gmail.com)

Received: 1 June 2012 - Published in Atmos. Chem. Phys. Discuss.: 6 July 2012

Revised: 10 December 2012 - Accepted: 11 January 2013 - Published: 21 January 2013

\begin{abstract}
Sources and evolution of ultrafine particles were investigated both horizontally and vertically in the large urban agglomerate of Barcelona, Spain. Within the SAPUSS project (Solving Aerosol Problems by Using Synergistic Strategies), a large number of instruments was deployed simultaneously at different monitoring sites (road, two urban background, regional background, urban tower $150 \mathrm{~m}$ a.s.l., urban background tower site $80 \mathrm{~m}$ a.s.l.) during a 4 week period in September-October 2010. Particle number concentrations $\left(N_{>5} \mathrm{~nm}\right)$ are highly correlated with black carbon (BC) at all sites only under strong vehicular traffic influences. By contrast, under cleaner atmospheric conditions (low condensation sink, CS) such correlation diverges towards much higher N/BC ratios at all sites, indicating additional sources of particles including secondary production of freshly nucleated particles. Size-resolved aerosol distributions $\left(N_{10-500}\right)$ as well as particle number concentrations $\left(N_{>5} \mathrm{~nm}\right)$ allow us to identify three types of nucleation and growth events: (1) a regional type event originating in the whole study region and impacting almost simultaneously the urban city of Barcelona and the surrounding urban background area; (2) a regional type event impacting only the regional background area but not the urban agglomerate; (3) an urban type event which originates only within the city centre but whose growth con-
\end{abstract}

tinues while transported away from the city to the regional background. Furthermore, during these clean air days, higher $N$ are found at tower level than at ground level only in the city centre whereas such a difference is not so pronounced at the remote urban background tower. In other words, this study suggests that the column of air above the city ground level possesses the optimal combination between low CS and high vapour source, hence enhancing the concentrations of freshly nucleated particles. By contrast, within stagnant polluted atmospheric conditions, higher $N$ and BC concentrations are always measured at ground level relative to tower level at all sites. Our study suggests that the city centre of Barcelona is a source of non-volatile traffic primary particles (29-39\% of $N_{>5 \mathrm{~nm}}$ ), but other sources, including secondary freshly nucleated particles contribute up to $61-71 \%$ of particle number $\left(N_{>5} \mathrm{~nm}\right)$ at all sites. We suggest that organic compounds evaporating from freshly emitted traffic particles are a possible candidate for new particle formation within the city and urban plume. 


\section{Introduction}

The quality of air we breathe is defined by a number of air pollutants that have adverse effects on human health and the environment. Ultrafine particles (UF) are defined as those with diameters smaller than $0.1 \mu \mathrm{m}(100 \mathrm{~nm})$, and make a dominant contribution to urban total particle number concentrations, but only a small contribution to particle volume or mass (Harrison and Yin 2000; Pope et al., 2002). Toxicological studies have suggested that UF are more toxic than coarser particles, per unit mass (Davidson et al., 2005; Seaton et al., 1995). Apportioning the sources of ultrafine particles has become of large interest in urban areas where population density and human activities are highly concentrated. Moreover, Reddington et al. (2011) recently stressed the importance of understanding the relative contribution of primary and secondary particles in regional and global aerosol so that models can attribute aerosol radiative forcing to different sources.

Sources contributing to particle number concentrations in the urban atmosphere are both primary and secondary. Traffic is often found to be the most important primary source for ultrafine particles in urban areas (Aalto et al., 2005; Morawska et al., 2008). In general, primary particles from vehicle exhaust can be divided into two broad categories, depending on the location of their formation. They can be formed in the engine (mostly 30-500 $\mathrm{nm}$ agglomerates of solid phase carbonaceous material) or in the atmosphere as the hot exhaust gases are expelled from the tailpipe of a vehicle (mostly smaller than $30 \mathrm{~nm}$, semi-volatile and consisting mainly of hydrocarbons and hydrated sulfuric acid) (Harrison et al., 2011). Particle formation in dilute engine exhaust depends strongly on meteorological factors (Zhang et al., 2004). For example, strong winds result in both higher particle numbers and smaller modal diameters (Charron and Harrison, 2003).

Secondary particles formed by nucleation are generated by gas-to-particle conversion. Such particles have been observed at many surface locations around the world and also within the free and upper troposphere (Kulmala et al., 2004). New particle formation events can occur on a large regional scale, and can impact urban areas (Stanier et al., 2004; Wehner et al., 2007; Hussein et al., 2009; Jeong et al., 2010; Boulon et al., 2011).

In general, new particle formation (NPF) events in the urban atmosphere are expected to be far less favoured than in the rural atmosphere due to the high existing surface area for condensation of non-volatile materials needed for homogeneous nucleation. Despite this, observational studies have suggested that new particle formation occurs in urban atmospheres (Harrison et al., 2000; McMurry et al., 2000). Depending on the location, nucleation events in urban atmospheres can occur on approximately $5 \%$ of the days observed (Alam et al., 2003) or up to 25-30\% (Stanier et al., 2004; Petaja et al., 2007; Pey et al., 2008; Salma et al., 2011).
Little is known about the vertical distribution of UF particles in the urban atmosphere. Urban UF flux cycles showed clear diurnal trends which were linked to traffic activity and local sources (Martin et al., 2009; Harrison et al., 2012). However, UF concentrations at urban street level are often found significantly higher than those at rooftop levels (Vakeva et al. 1999; Hitchins et al., 2002; Longley et al., 2003). Li et al. (2007) also reported that the particle number concentrations in both the nucleation mode and in the Aitken mode reduced significantly with height. By contrast, in one study short-time non-simultaneous measurements suggested larger concentrations of $5-30 \mathrm{~nm}$ aerosols at rooftop level than at street level (Kumar et al., 2009). Dall'Osto et al. (2011) recently provided compelling evidence for the volatile loss of semi-volatile hydrocarbon components of the aerosol during advection of traffic-generated particles into a park and vertical transfer to a tower $160 \mathrm{~m}$ above ground level. At the tower site, within one hour the traffic nucleation mode particles are totally lost by evaporation from the measured size distribution having shrunk to below $5 \mathrm{~nm}$ diameter (Dall'Osto et al., 2011).

Even less is known about the vertical distribution of secondary new UF particles, especially in the urban atmosphere. The location of NPF is still uncertain, with evidence for both new aerosol particle formation at the surface layer mixing upwards (O'Dowd et al., 2009) and nucleation occurring aloft and subsequently blended downwards (Siebert et al., 2004; Stanier et al., 2004). Up to which altitude these NPF events take place, and where they are initiated is still under debate. Crumeyrolle et al. (2010) observed that NPF events were limited to the boundary layer while Hamburger et al. (2011) have observed high concentrations of ultrafine particles in the upper free troposphere. Wehner et al. (2010) observed peaks in the number concentrations of ultrafine aerosol particles at ground level connected with new aerosol particle formation in the residual layer by boundary layer development and vertical mixing, and Pryor et al. (2011) concluded that the spatial variation of the ultrafine particle concentrations was due to in situ production rather than horizontal advection. The occurrence of new particle formation episodes depends on various factors including the emission strength of precursors, composition and number concentration of pre-existing aerosol population, meteorological parameters (in particular solar radiation, temperature and relative humidity) and photochemical processes (Kulmala et al., 2001, 2004).

In summary, the evolution of primary anthropogenic particles and the formation of new secondary particles still remains one of the greatest challenges in urban atmospheric aerosol research. Primary and secondary UF particles may have different chemical composition and hence different toxicity. Furthermore, UF particles generated in urban areas are important sources of cloud condensation nuclei $(\mathrm{CCN})$, and hence important for the climate (Spracklen et al., 2008, 2010). 
This study aims to provide extensive measurements on particle number concentrations in urban air, including in the vertical above the surface where highly dynamic conditions may play a role. The study area is a large urban European Mediterranean agglomerate which, under high solar irradiance, is a very favourable location for nucleation processes. Pey et al. (2008) first studied events and cycles of urban aerosols in the western Mediterranean, and a follow-up study (Pey et al., 2009) reported source apportionment of urban fine and ultrafine particle number concentration, with traffic being by far the most important component (69\%). Recently, Reche et al. (2011) elaborated new considerations for black carbon (BC) and particle number concentrations $(N)$ for air quality monitoring across different European cities, showing that in Barcelona nucleation events can occur in the middle of the day all year round. In this work, we extend previous measurements by using a three-dimensional measurement approach to study the sources and the evolution of UF particles.

\section{Methodology}

\subsection{SAPUSS project and measurement sites}

The SAPUSS campaign (Dall'Osto et al., 2012a) was carried out in the region of Barcelona, a city located in the Western Mediterranean Basin (WMB) in the North East (NE) part of Spain. With a population of about 1.7 million inhabitants in the city and around 4 million in the surrounding area, Barcelona is the fifth most populated metropolitan area in Europe. The sampling campaign took place between 20 September and 20 October 2010 (local time, UTC+2). The unique approach involved a large variety of instrumentation deployed simultaneously at 5 monitoring sites in the metropolitan area, shown in Fig. S1 in the Supplement and a regional background site:

- Road site (RS, $\left.41^{\circ} 23^{\prime} 18^{\prime \prime} \mathrm{N} ; 02^{\circ} 09^{\prime} 0^{\prime \prime} \mathrm{E}\right)$ was situated in a car park next to $\mathrm{C} /$ Urgell, a major highway composed of a one-way four lane road. Vehicle intensity for the measurement period was about 17000 vehicles per day.

- Urban Background site (UB, $41^{\circ} 23^{\prime} 15^{\prime \prime} \mathrm{N}$, $02^{\circ} 07^{\prime} 05^{\prime \prime} \mathrm{E}$ ) was situated at the North Western periphery of the city centre in a small park (elevation $80 \mathrm{~m}$ a.s.l.) situated about $6 \mathrm{~km}$ from the sea. This monitoring site was used in previous studies, providing important information on the variability of UF particles in Barcelona (Pey et al., 2008, 2009; Reche et al., 2011).

- Tower Mapfre site (TM, $\left.41^{\circ} 23^{\prime} 16^{\prime \prime} \mathrm{N}, 2^{\circ} 11^{\prime} 51^{\prime \prime} \mathrm{E}\right)$ is a skyscraper (154 m a.s.l) in the Port Olímpic, about 200 $\mathrm{m}$ from the sea. A large recreational area, as well as ring road motorways can be found at street level.
- Tower Collserola site (TC, $\left.41^{\circ} 25^{\prime} 02^{\prime \prime} \mathrm{N}, 02^{\circ} 06^{\prime} 51^{\prime \prime} \mathrm{E}\right)$ is a telecommunications tower located at $445 \mathrm{~m}$ a.s.l. Measurements were taken on the fourth floor, at $80 \mathrm{~m}$ above ground level (525 $\mathrm{m}$ a.s.l.).

- Due to both limited access and space at the TC monitoring site, the Fabra Observatory $\left(41^{\circ} 25^{\prime} 56^{\prime \prime} \mathrm{N}\right.$, $2^{\circ} 07^{\prime} 27^{\prime \prime} \mathrm{E}$ ) was also used as a monitoring site during the SAPUSS project. The Fabra Observatory is an astronomical observatory at $415 \mathrm{~m}$ altitude above sea-level, and located about $450 \mathrm{~m}$ ( $900 \mathrm{~m}$ road distance) from the TC site. Measurements were taken on the terrace at about $10 \mathrm{~m}$ from the ground. Although not ideal, we treat the Collserola Tower (TC) and the Fabra Observatory ( $\mathrm{TC}$ ground, $\mathrm{TCg}$ ) as one monitoring site, but we will clearly state when measurements were taken at ground level (TCg, $10 \mathrm{~m}$ above ground, $425 \mathrm{~m}$ a.s.1.) or at higher level (TC, $80 \mathrm{~m}$ above ground, $525 \mathrm{~m}$ a.s.l). Is is important to note that whilst TM is well within the Barcelona urban city centre, TC is located in the hills of the urban background of Barcelona (Fig. S1 in the Supplement).

- Montseny Regional Background site (RB, $41^{\circ} 46^{\prime} 45^{\prime \prime} \mathrm{N}$ $02^{\circ} 21^{\prime} 29^{\prime \prime} \mathrm{E}$ ) is part of the EUSAAR network (European Supersites for Atmospheric Aerosol Research, www.eusaar.net, abbreviation "MSY") and is located within a regional natural park about $50 \mathrm{~km}$ to the NorthNorth East side of the city of Barcelona and about $30 \mathrm{~km}$ from the Mediterranean coast (Dall'Osto et al., 2012a). This RB site is only used in this study to describe different nucleation events presented in Sect. 3.3.

In summary (see Fig. S1 in the Supplement), the RS site and the TM site are located in the core of the busy city centre of Barcelona, at ground level and at about $154 \mathrm{~m}$ a.s.l., respectively. In contrast, the UB site is more representative of the urban background conditions at ground level. Additionally, the TCg and the TC sites are indicative of the outskirts of the Barcelona agglomerate, and are confined to the hills ( $\mathrm{TCg}$, $10 \mathrm{~m}$ above ground, $425 \mathrm{~m}$ a.s.1. and TC, $80 \mathrm{~m}$ above ground, $525 \mathrm{~m}$ a.s.l., respectively) about $4 \mathrm{~km}$ from the city centre. Finally, the RB site reflects more the regional background conditions. It is worthwhile to stress that the two monitoring towers are the tallest buildings within several kilometres of the sites (Fig. S1), with good exposure to winds from all directions. The TCg, TC and RB sites are all aligned with the Barcelona city centre in a position to receive urban plumes from the city, especially in the afternoon when the sea breeze arrives from the South-West encountering in order: TM, RS, $\mathrm{UB}$, followed by $\mathrm{TCg}-\mathrm{TC}$, and then RB. 


\subsection{Instrumentation}

\subsubsection{Meteorological and remote sensing parameters}

Meteorological variables (atmospheric pressure, wind components, solar radiation, temperature and relative humidity) were recorded at all the SAPUSS monitoring sites during the whole field study. The atmospheric boundary layer (ABL) above Barcelona was monitored by simultaneous measurements of two Jenoptik CHM15K LIDAR ceilometers (Heese et al., 2010; Martucci et al., 2010) with $1064 \mathrm{~nm}$ wavelength and $15 \mathrm{~km}$ vertical range. The ABL height and vertical structure can be retrieved with standard $30 \mathrm{~s}$ and $15 \mathrm{~min}$ temporal and vertical resolution, respectively, by applying the Temporal-Height-Tracking (THT, Martucci et al., 2010; Haeffelin et al., 2011) algorithm to the LIDAR returns from the CHM15K). The vertical profiles of atmospheric temperature, pressure and relative humidity as well as wind components were also obtained by radiosoundings performed twice per day (at 12:00 UTC and 00:00 UTC) at the UB site.

\subsubsection{Aerosol properties}

Total particle number concentrations were measured at all the SAPUSS monitoring sites. The same type of Condensation Particle Counter (CPC) (TSI CPC Model 3022A; lower $50 \%$ cut-point $7 \mathrm{~nm}$ ) was simultaneously deployed at 3 of the SAPUSS sites (RS, TM, TC), whilst the instruments at the RB and UB sites were TSI water based (WB) CPCs 3785 (with a lower $50 \%$ cut-point at $5 \mathrm{~nm}$ ) which would lead to slightly higher readings relative to the Model 3022A instrument. Instruments were inter-compared before and after the campaign, giving excellent agreement, with uncertainty of about $5 \%$ both before and after the campaign. CPC data capture ranged between $65 \%$ and $83 \%$, with simultaneous measurements at four sites taken for $55 \%$ of the time (Fig. S2). Nano CPCs (TSI 3025 and TSI WB 3786, $50 \%$ cut-point at $3 \mathrm{~nm}$ ) were also located at the TM tower site (20-27 September 2010) and at the TC tower site (24-26 September 2010), respectively. A number of different Scanning Mobility Particle Sizer (SMPS) systems were deployed simultaneously at 4 different sites (Fig. S3), providing size resolved aerosol particle number concentrations. In summary, during the SAPUSS experiment there was a total of 4 Differential Mobility Analysers (DMAs) and 11 CPCs deployed. Black Carbon mass was derived by light absorption using both a McGee Scientific aethalometer AE 16 and a Multi-Angle Absorption Photometer (MAAP). A total of 4 MAAP instruments were deployed most of the time during the SAPUSS whereas an aethalometer was deployed at the TM site. MAAP instruments gave excellent agreement between them (within 5\%). The MAAPs and the aethalometer were inter-compared before and after the field study, also giving excellent agreement.

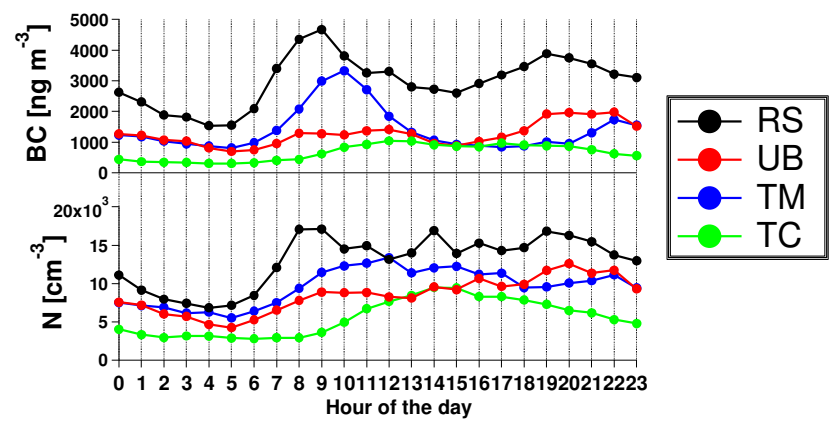

Fig. 1. Diurnal profile of $\mathrm{BC}$ and $N$ at four different monitoring sites.

\section{Results}

\subsection{N and BC concentrations across different monitoring sites}

The highest concentration of averaged particle number concentrations $(N)$ was found at the RS $\left(12890 \pm 6300 \mathrm{~cm}^{-3}\right)$, followed by UB $\left(10490 \pm 5900 \mathrm{~cm}^{-3}\right)$, TM $\left(9588 \pm 6400 \mathrm{~cm}^{-3}\right)$ and TC $\left(5500 \pm 3800 \mathrm{~cm}^{-3}\right)$ sites. Previous studies at the UB (Reche et al., 2011) reported higher values for the 2009 annual mean (about $17000 \pm 5000 \mathrm{~cm}^{-3}$ ), although similar values were seen when considering the 2010 SAPUSS annual mean (about $12000 \pm 4000 \mathrm{~cm}^{-3}$ ) (C. Reche, personal communication, 2013). A similar trend was seen for BC: the highest values for $\mathrm{RS}\left(2987 \pm 1700 \mathrm{ng} \mathrm{m}^{-3}\right)$, followed by UB $\left(1350 \pm 1100 \mathrm{ng} \mathrm{m}^{-3}\right)$, TM $\left(1405 \pm 1500 \mathrm{ng} \mathrm{m}^{-3}\right)$ and TC $\left(650 \pm 450 \mathrm{ng} \mathrm{m}^{-3}\right)$. This is consistent with road traffic being a major source of both $\mathrm{BC}$ and $N$. The slightly higher value of $\mathrm{BC}$ at the TM site relative to UB is likely due to the busy highways and roads found below the TM site. The diurnal variation of $\mathrm{BC}$ and $N$ for the four different sites is presented in Fig. 1. As expected, the BC trends show a marked profile peaking during the morning and evening traffic rush hours at the urban sites RS, UB and TM. In contrast, the TC site shows a peak in the late morning due to the fact that the urban pollution arrives at this background location at a later time, when the boundary layer is fully developed and the sea breeze commences, bringing plumes from the city to the TC site. The diurnal trends of $N$ are more complex and do not always follow those for BC. Reche et al. (2011) have already extensively described the variability of $N$ and BC levels across different European areas. Although in central and northern Europe, $N$ and $\mathrm{BC}$ levels tend to vary simultaneously, not only during the traffic rush hours but also during the whole day, in urban background stations in southern Europe maximum $N$ levels coinciding with minimum BC levels and attributed to nucleation episodes are recorded at midday in all seasons. Within the SAPUSS campaign (Fig. 1), a strong peak in $N$ 
Table 1. Average $N$ and BC concentrations for weekdays (WD) and weekend (WE) days and relative difference (WD-WE) at four different monitoring sites; and ratios of $N / \mathrm{BC}$ for different air mass scenarios.

\begin{tabular}{|c|c|c|c|c|c|c|c|c|c|}
\hline \multirow{2}{*}{ Site } & \multicolumn{3}{|c|}{$N \quad$ [particle $\left.\mathrm{cm}^{-3}\right]$} & \multicolumn{3}{|c|}{$\mathrm{BC}\left[\mathrm{ng} \mathrm{m}^{-3}\right]$} & \multicolumn{3}{|c|}{$N / \mathrm{BC}\left[\right.$ particle $\mathrm{cm}^{-3} / \mathrm{ng} \mathrm{m}^{-3}$ ] } \\
\hline & WD & WE & $\begin{array}{l}\% \\
\text { WD- } \\
\text { WE }\end{array}$ & WD & WE & $\begin{array}{l}\% \\
\text { WD- } \\
\text { WE }\end{array}$ & $\begin{array}{l}\text { All air } \\
\text { masses }\end{array}$ & $\begin{array}{l}\text { Marine } \\
(\mathrm{mP})\end{array}$ & $\begin{array}{l}\text { Continental } \\
\text { (cP) }\end{array}$ \\
\hline RS & 15124 & 9355 & 38 & 3650 & 2245 & 38 & 4 & 4 & 4 \\
\hline UB & 13058 & 9722 & 26 & 1394 & 1182 & 22 & 8 & 10 & 7 \\
\hline $\mathrm{TM}$ & 9856 & 9005 & 9 & 1583 & 1009 & 36 & 8 & 14 & 8 \\
\hline $\mathrm{TC}$ & 6190 & 4613 & 25 & 748 & 547 & 27 & 7 & 11 & 5 \\
\hline
\end{tabular}

is observed in the morning for the ground sites UB and RS, whereas the tower sites TM and TC do not follow the BC diurnal profiles. $N$ concentrations at TM show a slow-rising daytime elevation. Similar behaviour is seen also at the TC site: a broader peak between 11:00 and 19:00 peaking at 15:00 (Fig.1). When considering the weekdays/weekend (WD-WE) variability, all the sites present a reduction for both $N$ and $\mathrm{BC}$ concentrations (Table 1), implying a strong traffic influence on $N$ and $\mathrm{BC}$ concentrations. The RS shows remarkably similar reduction for both $N$ and BC (38\%). TC also presented similar reduction for $N$ and $\mathrm{BC}(25-26 \%)$, whereas a smaller reduction was seen for the UB site for $N$ $(18 \%)$ than BC (25\%). The WD-WE variation at the tower $\mathrm{TM}$ site shows a strong reduction for the $\mathrm{BC}$ concentrations ( $35 \%$, similar to the road RS site) but a much smaller one for $N(9 \%)$.

Size resolved particle number concentrations have been classically described as a function of air mass type (marine, continental, mixed) (Birmili et al., 2001; O'Dowd, 2001). Air masses of different origins have different meteorological, physical and chemical characteristics, and for example the probability of occurrence of NPF events at a given location and time depend not only on local emissions, but also on long range transport (Sogacheva et al., 2007; Tunved et al., 2006). Figure 2 shows the $\mathrm{BC}$ and $N$ concentrations for different air mass types encountered during the SAPUSS study. Out of 30 days of measurements, 9 were classified as $\mathrm{cP}$ (Continental Polar, or regional stagnant air masses scenarios) and 7 as $\mathrm{mP}$ (marine Polar, or Atlantic air mass scenarios, intensive cold advections from the Atlantic Ocean) (Dall'Osto et al., 2012a).

The $\mathrm{BC}$ concentrations presented a similar trend for all four sites: the lowest concentration was detected under $\mathrm{mP}$ conditions whereas the highest were associated with the $\mathrm{cP}$ category (Fig. 2). It is important to remember that air arriving from the Atlantic will in most cases have traversed all of Spain (and possibly Portugal) and therefore collected significant pollution on the way. However, the main significance of $\mathrm{mP}$ air masses is that they are faster moving and therefore cause enhanced dilution of local pollutants. By contrast, an opposite trend was seen for $N$ : the highest concentrations

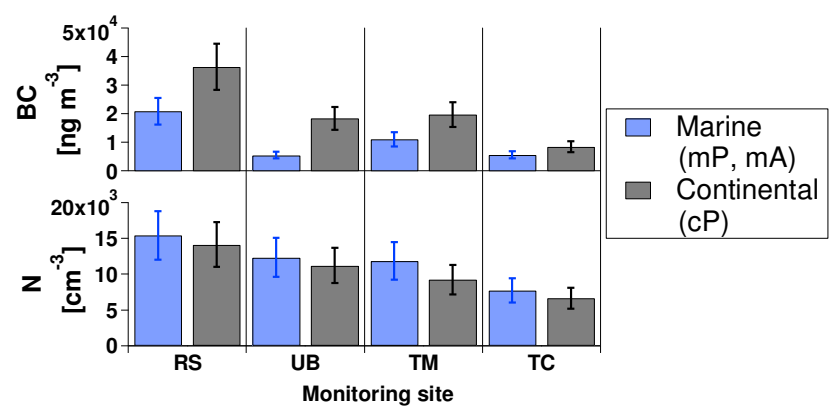

Fig. 2. Average $\mathrm{BC}$ and $N$ concentrations under different air mass back trajectories scenarios at four different monitoring sites.

were recorded during the $\mathrm{mP}$ air mass type. Table 1 shows the ratio between $N$ and the more conservative variable $\mathrm{BC}$ (Reche et al., 2011, Dall'Osto et al., 2011). When considering all the data, a lower $N / \mathrm{BC}$ ratio is seen for the RS relative to all the other three, remaining constant at about $4 \mathrm{~cm}^{-3} / \mathrm{ng} \mathrm{m}^{-3}$ under different air masses (Table 1). However, the other sites present very different ratios under different air mass scenarios, implying different evolution of particles leaving the main traffic source as well as contributions from secondary particles and from primary particles from other non-traffic sources.

\subsection{Nucleation events}

Newly formed nucleating particles are typically of size 1$2 \mathrm{~nm}$ in diameter and not easily measurable by current routine particle counting techniques. The classification of nucleation events is as yet somewhat subjective as a standardised method does not exist. It is important to bear in mind that, within the urban atmosphere, great care has to be taken when assigning nucleation events, as UF traffic plumes or growth of existing UF can be wrongly assigned as nucleation events. In other words, primary emissions or growth of primary emitted urban UF particles cannot be classified as new nucleation events. In order to identify the nucleation events during SAPUSS, we used two different methodologies. The first method was based upon tandem particle counters with 


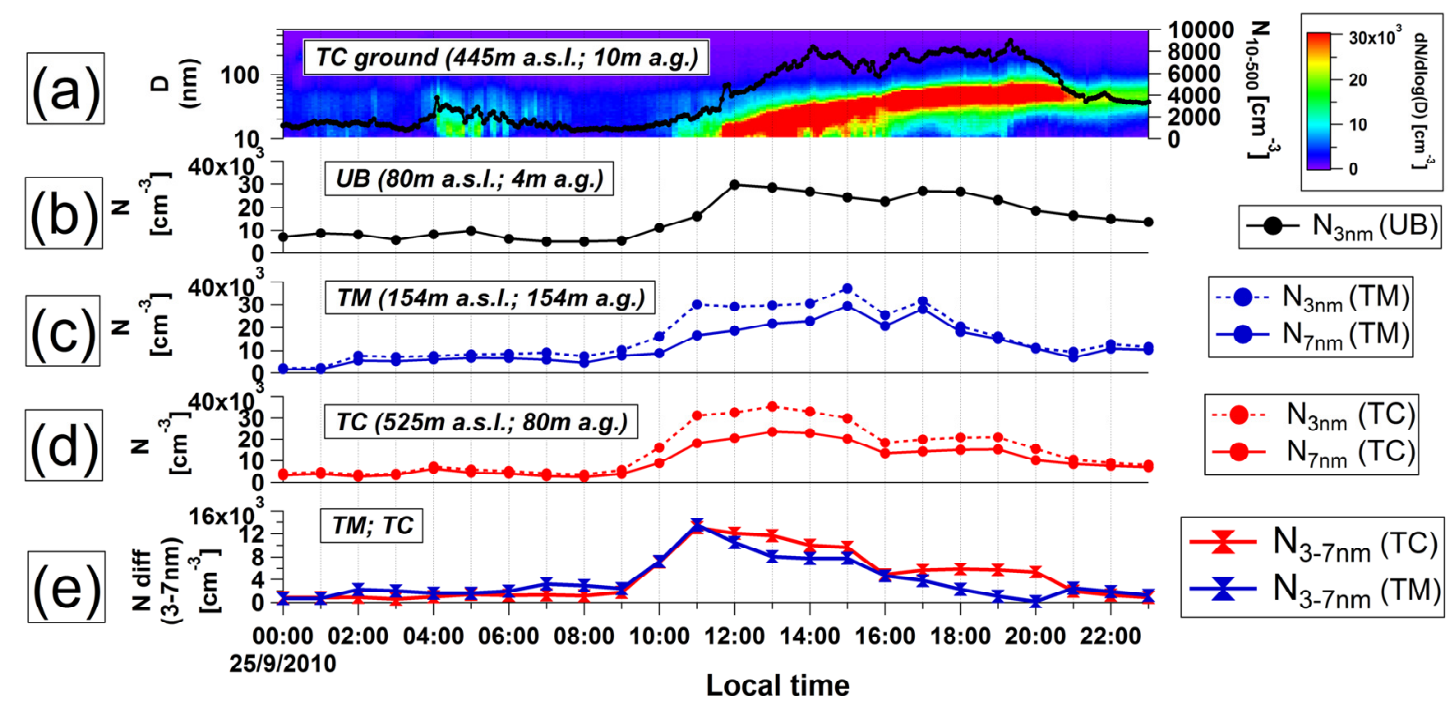

Fig. 3. (a-e). Regional nucleation event observed on 25 September 2010.

lower detection limits (50\% efficiency of detection) of 3 and $7 \mathrm{~nm}$ (respectively). The measured difference in $N$ within the size range $3-7 \mathrm{~nm}$ gives an indication of particles recently nucleated (Alam et al., 2003). The second method was that proposed by Dal Maso et al. (2005), where SMPS plots were visually analyzed and several criteria had to be met to classify a NPF event such as: (1) a distinctly new mode of particles must appear in the size distribution; (2) the mode starts in the nucleation mode size range; (3) the mode prevails over a time period of hours, and (4) the new mode shows signs of growth. Nucleation burst particle formation events can be usually classified into two groups, with and without particle growth after the burst of nucleation mode particles observed (Vana et al., 2008, Cheung et al 2011). During SAPUSS, only three days could be unambiguously assigned to nucleation events and are described in the following two sections. However, on at least another three days, very high values of $N$ were measured, indicating bursts of nucleation monitored by CPCs $\left(D_{>5 \mathrm{~nm}}\right)$ but not by SMPSs $\left(D_{>10 \mathrm{~nm}}\right)$. This suggests that nucleation processes, with and without growth, were affecting the SAPUSS study period on about $20 \%$ of the days, stressing the importance of nucleation events in the Mediterranean urban regions relative to colder Northern European urban environments.

\subsubsection{Regional nucleation: "regional" nucleation event and "regional background" nucleation event}

\section{Aerosol properties}

A clear regional nucleation event was detected simultaneously at the four different urban sites on 25 September 2010. This event was detected across the entire city, and the SMPS data present the typical "banana" shape (Kulmala et al., 2004). This is seen clearly in the ground level data of the
Fabra observatory (TCg, Fig. 3a) consistent with particle number concentrations seen at the ground level UB (Fig. 3b), and the two tower sites of TC (Fig. 3c) and TM (Fig. 3d). Unfortunately, neither particle number concentrations nor aerosol size distributions were available for this day at the RB and RS sites. In summary, for this day SMPS systems were running optimally only at $\mathrm{TCg}$, whereas CPCs were running well at the TC, TM and UB (Fig. 3). The high values of $N$ (Fig. 3b-d) measured after the particle burst (about 11 a.m.) at all sites suggest that particles generated from this regional nucleation event were elevated at all monitoring sites, hence reflecting the same conditions as the SMPS deployed at the $\mathrm{TC}$ and reported in Fig. 3a. The event covers an area of at least $10 \mathrm{~km}^{2}$ in a column of air at least $525 \mathrm{~m}$ high. This nucleation event was found to occur simultaneously in the city centre (TM, UB) as well as in the urban background locations ( $\mathrm{TC}, \mathrm{TCg}$ ), and was homogeneously distributed across the vertical profile of the urban boundary layer. Whilst the maximum $N$ at both sites above ground (TM, TC) occurs at 10:00-11:00, the maximum $N$ at both sites at ground-level (TCg, UB) occurs at 11:00-12:00; suggesting this nucleation event may have initiated above the urban surface.

A second nucleation event was detected on 17 October 2010 and it is presented in Fig. 4 (regional background nucleation event). By contrast, this event was found only to occur in the regional background site (RB, $30 \mathrm{~km}$ from the urban agglomerate) but not in the city centre (RS) or in the urban background area (UB). It was found to start at about 09:00 a.m. UTC and it presented the typical "banana" shape, reaching CCN sizes (about $80 \mathrm{~nm}$ ) after continuous growth until about 15:00. This event was found to be begin along with a spike of $\mathrm{SO}_{2}$ concentration detected at the RB site, and more information can be found in Sects. 4 and 5 . 


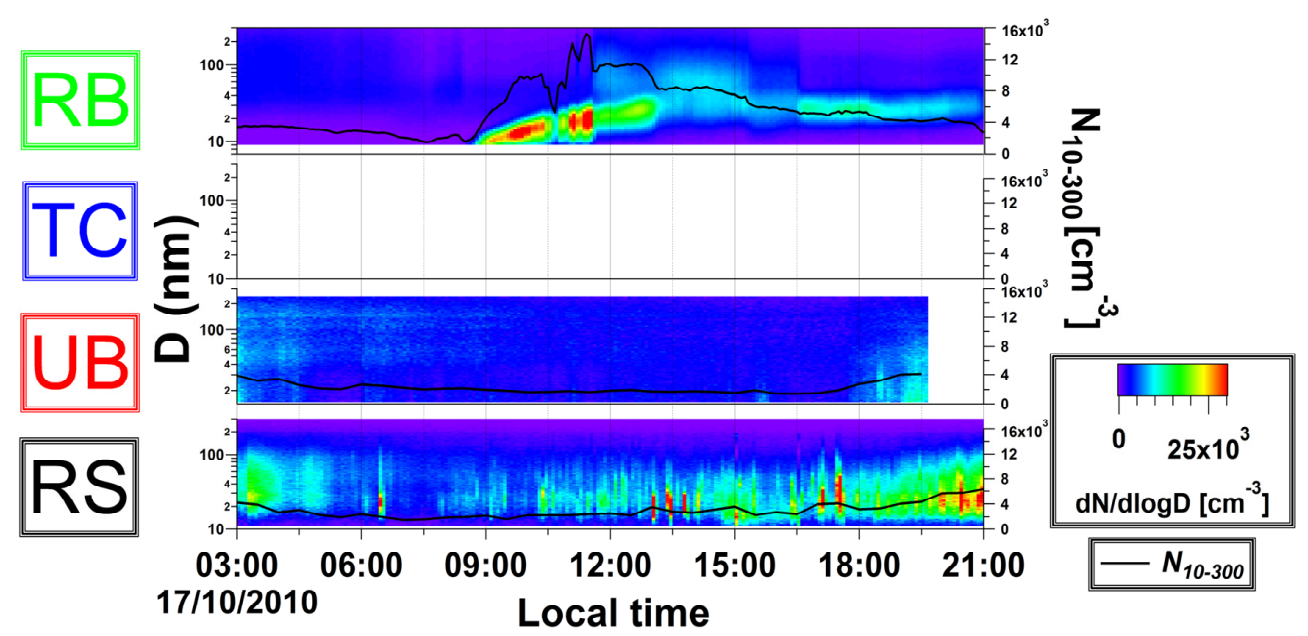

Fig. 4. Aerosol size-resolved particle number concentrations at different monitoring sites during a regional background nucleation event on 17 October 2010. Data for the TC site were not available.

\section{Meteorological parameters}

The variations of the meteorological parameters for these regional nucleation events were compared with the other days of the field study. Very low values of RH were found during the regional nucleation events at all monitoring sites ( $\mathrm{RH}<40 \%$ between 11:00 and 15:00). This is also seen in the driest air columns encountered during the 32 daily radio soundings recorded during SAPUSS (Fig. S4). A unique feature for the regional nucleation event (Fig. 3) was also the maximum hourly radiation intensity value during this day $\left(781 \mathrm{~W} \mathrm{~m}^{-2}\right.$ at 13:00), the second highest value recorded during the whole study. As regards the regional background nucleation event (Fig. 4), the only exceptional meteorological conditions were the dry and cold air mass associated with the event (see Fig. S4 in the Supplement).

It has been observed at various continental locations that NPF takes place preferentially at low RH (Laaksonen et al., 2009). Hamed et al. (2011) suggested that the increase of coagulation scavenging plays a relatively small role in the inhibition of nucleation at high RH. On the other hand according to Hamed et al. (2011), the low OH concentrations at high $\mathrm{RH}$ limits $\mathrm{H}_{2} \mathrm{SO}_{4}$ levels in the air, concluding that high new particle formation rates rarely occur above $80 \% \mathrm{RH}$. It is our view that low relative humidities will lead to shrinkage of hygroscopic particles reducing the available CS and favouring nucleation. Although solar radiation is likely the trigger for this nucleation event, other meteorological conditions may also influence the new particle formation process. For example, Peter et al. (2010) reported enhanced NPF events associated with mixing between air masses of distinct thermodynamic properties, suggesting that large gradients in temperature and relative humidity may have promoted new particle formation via turbulent mixing. The regional nucleation event occurred after a persistent typical summer recir- culation pattern, with low pressure gradients over the western Mediterranean basin (19-22 September) and a second brief period (23-24 September) characterized by the advection of southern air from North Africa, with intrusion of Saharan Dust. During the evening of 24 September 2010, air masses changed to a marine Polar trajectory originated from the North Atlantic (Fig. S5). This was associated with the strongest wind speed recorded during SAPUSS on 25 September, coming from the North and recorded homogenously across the air column (see radio sounding profile of Fig. S4). The boundary layer was found to grow convectively at about $08: 30$, reaching a maximum height of $1050 \mathrm{~m}$ at about 13:30 (Fig. S5a) and then progressively decreasing. The boundary layer height after 9:00 was found to be $970 \pm 250 \mathrm{~m}$, well above all monitoring sites (Fig. S5a). Similar conditions were found for the regional background nucleation event (Fig. S4b in the Supplement): it occurred on 17 October 2010 after a persistent typical Mediterranean recirculation pattern (13-17 October 2010), within a marine Polar air mass originated from the North Atlantic, with a boundary layer which started growing convectively at about 08:30 (Fig. S5b in the Supplement).

\subsubsection{Urban nucleation events}

\section{Aerosol properties}

Based on CPC measurements, Reche et al. (2011) recently reported annual mean maximum $N$ levels at midday in Barcelona, indicating that nucleation events occur all year round. However, in the absence of SMPS measurements it is difficult to monitor such NPF events. When measuring size resolved particle concentrations larger than $13 \mathrm{~nm}$ across a whole year near the SAPUSS UB site, photochemically induced nucleation particles make only a very small contribution to the total particle number concentration $(2-3 \%$ of the 


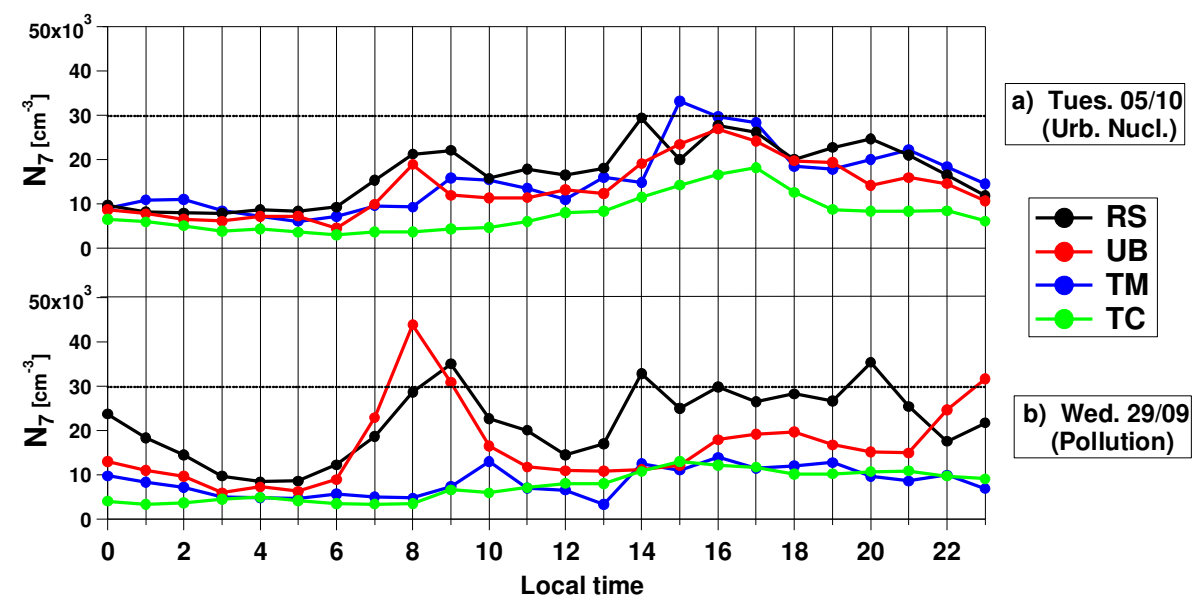

Fig. 5. Diurnal variations of the particle number concentrations for (a) Urban nucleation event day on 5 October 2010 and (b) typical polluted day (29 September 2010) at four different monitoring sites.

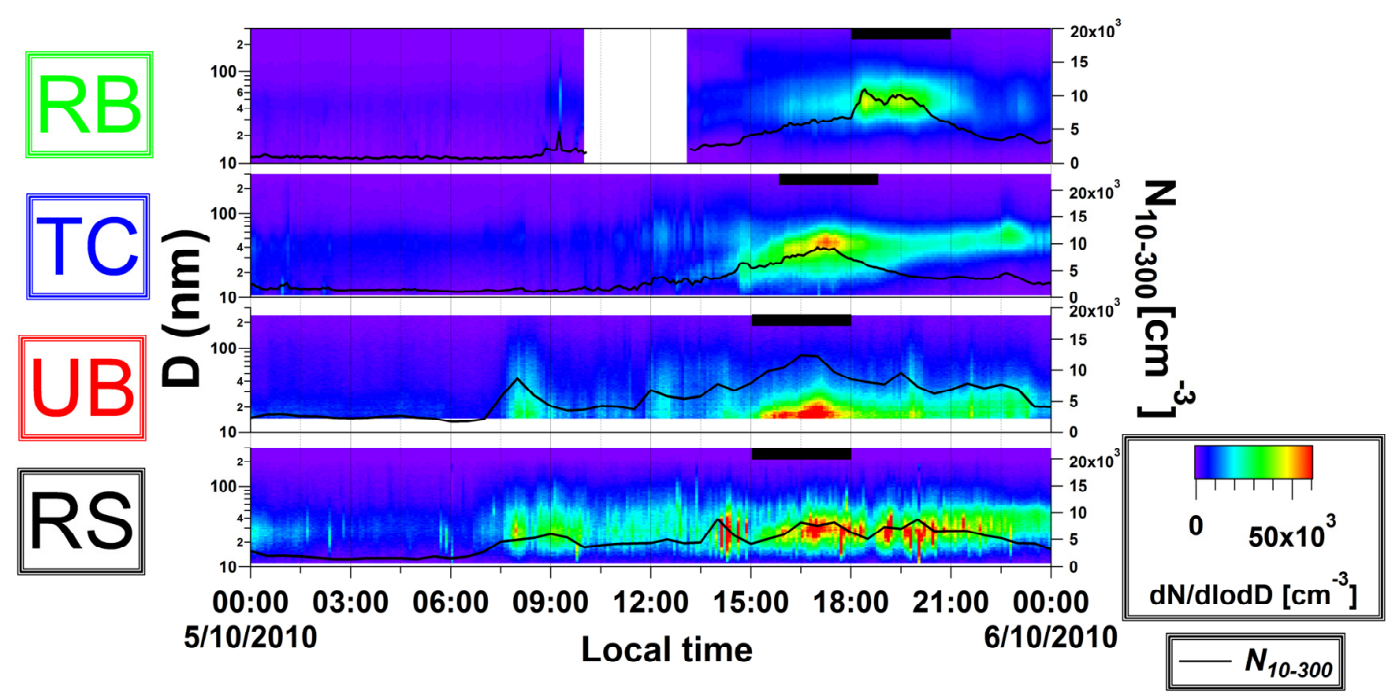

Fig. 6. Aerosol size-resolved particle number concentrations at four different monitoring sites during the urban nucleation event on 5 October 2010 .

total) (Dall'Osto et al., 2012b). In other words, the city is a source of new secondary particles, but such particles often fail to grow above the SMPS detection limit of about $10 \mathrm{~nm}$ (Dall'Osto et al., 2012b). This only implies that nucleating particles cannot easily grow within the urban agglomerate of Barcelona, but it is not known if such particles are able to grow while being transported away from the city centre with the afternoon sea breeze typical of Mediterranean coastal urban agglomerates. However, our study seems to support such a hypothesis. Indeed, a second type of nucleation event, initiating only in the urban centre of Barcelona and not across the whole region, was observed during the SAPUSS campaign, Fig. 5a. Afternoon values for $N$ are higher than those in the morning at the ground sites UB and RS. The tower site within the city (TM) is surprisingly found to possess even higher af- ternoon $N$ concentrations relative to the ground sites. The TC also shows an increased $N$ concentration in the afternoon period, but peaking later at about 17:00. This is in contrast to the more general behaviour encountered during stagnant polluted days, Fig. 5b (29 September 2010, taken as an example), where a strong morning rush hour traffic peak is seen for both ground sites RS and UB. Furthermore, higher particle number concentrations can be seen for both ground sites (RS, UB) relative to the tower sites (TM, TC) at all hours of the day. A slight increase in $N$ is seen for the TM at 10:00 and in the afternoon, whereas a more constant pattern can be seen for the TC site on the day affected only by pollution.

By deploying simultaneously four SMPS instruments, a clear evolution of the nucleation event can be better seen in Fig. 6: nucleating particles increase in concentration in the 
city centre (RS and UB) at around 14:00, and are subsequently transported by the sea breeze (wind direction 150$200^{\circ}$, see Fig. S1 and Dall'Osto et al., 2012a) to the background tower (TC) and to the regional background site (RB) in the evening. This strongly suggests that this type of nucleation event begins in the urban areas of Barcelona and its growth continues as the plume travels away from the city (see also aerosol size distributions in Fig. S6). When calculating the growth rate, a constant pool of nanoparticles was seen at both the ground sites RS and UB, with a constant unimodal distribution centred at about $16 \pm 2 \mathrm{~nm}$ between 15:00 and 18:00 at the UB. In contrast, a growth rate of about $2.7 \mathrm{~nm} \mathrm{~h}^{-1}$ can be seen at the TC site from 15:30 $(23 \pm 7 \mathrm{~nm})$ to $18: 00(35 \pm 2 \mathrm{~nm})$. A lower growth rate was seen at the regional site RB: $2.1 \mathrm{~nm} \mathrm{~h}^{-1}$ from 16:30 (37 $\left.\pm 2 \mathrm{~nm}\right)$ to $19: 30$ $(48 \pm 2 \mathrm{~nm})$, indicating a decrease of the growth rate with the distance from the city centre (Fig. 6).

\section{Meteorological properties}

The urban nucleation event on 5 October 2010 was associated with the strongest radiation intensity during the entire SAPUSS study. However, it presented dry intermediate $\mathrm{RH}$ conditions $(52 \%)$ and average temperatures $\left(19.8^{\circ} \mathrm{C}\right)$. The radio sounding measurements taken during this day also present average conditions with no peculiar feature in any of the parameters measured (Fig. S4). The beginning of the nucleation event was recorded by the SMPS at about 15:00, coincident with the maximum hourly average temperature of the day whereas the maximum solar radiation intensity $\left(860 \mathrm{~W} \mathrm{~m}^{-2}\right)$ was found at 13:00. However, nucleation must have commenced earlier in order for particles to grow to the lower limit of the SMPS. Like the regional nucleation events, this urban nucleation event also occurred after a persistent typical summer recirculation pattern (29 September-2 October) and a second brief period of southern air from North Africa (2-4 October). During the evening of 4 October 2010, the air masses changed to a marine Polar trajectory originating from the North Atlantic (Fig. S5c). With regard to the boundary layer structure, a marked difference relative to the regional nucleation event can be seen: some light cloud present till 11:30 limited the convective growth of the PBL (Fig. S5c in the Supplement). Boundary layer depths for this day were found similar in the afternoon, well above all the monitoring sites (>1200 m, Fig. S5c).

\section{Analysis}

\subsection{Origin of the nucleation events}

The first step in a nucleation event is the formation of an initial nucleus, followed by growth of the particles to larger sizes. In the continental boundary layer so-called "regional nucleation events" are common. Observed aerosol forma- tion events very often, if not always, occur during daytime, as photochemistry plays a central role in this process. Such events can cover large spatial scales. For example, Wehner et al. (2007) found that new particle formation events vertically well mixed within the entire boundary layer occurred at all monitoring sites located more than $400 \mathrm{~km}$ apart. However, the nucleation phenomenon could be interrupted when clouds were limiting the incoming solar radiation. Factors that favour atmospheric aerosol nucleation include a sufficiently low pre-existing aerosol concentration, low relative humidity, and a high vapour source production rate. The most important of these factors seem to be the high vapour source rate and the low sink due to pre-existing particles (Kulmala and Kerminen, 2008).

The conditions associated with the regional nucleation events detected during SAPUSS centre upon the incursion of cool and very dry air masses (Fig. S4, S5 in the Supplement) associated with the passage of a cold front leading to stronger winds and probably strong turbulent mixing. Numerical calculations have shown that the mixing of two air parcels with different properties such as precursor concentration, temperature and relative humidity generates more particles through nucleation than would be the case for the two air parcels separately (Nilsson and Kulmala, 1998; Jaenisch et al., 1997; Khosrawi and Konopka, 2003).

As regards the time of nucleation, these regional events were observed in the late morning (09:00 to 12:00), and were associated with a clear transition from an atmosphere with low turbulence intensity and weak vertical velocities, to much a weaker vertical gradient of wind speed, increased turbulence intensity and stronger downwards vertical velocities, consistent with growth of the mixed layer and entrainment of air from the residual layer, as recently summarised by Pryor et al. (2011).

By contrast, whilst the urban nucleation event was also associated with $\mathrm{mP}$ air mass back trajectories, it did not present any unique meteorological features like the regional events. The urban nucleation event occurred in the afternoon and was not linked with the morning urban boundary layer dynamics. The only meteorological variable peaking at 15:00 was found to be the temperature, with wind speed being at maximum level 15:00-17:00. In this regard, it is important to remember that when turbulence weakens in the afternoon, due to the decreasing sensible heat flux, the temperature inversion builds up again and the depth over which mixing occurs becomes shallower. In these afternoons and after-sunset conditions, the strongest aerosol gradient corresponds to a residual aerosol layer above the actual surface mixed layer (Haeffelin et al., 2011). Indeed, Fig. S5c shows a lower boundary layer at 14:30-15:00 which may have affected the urban nucleation event.

However, meteorological conditions are not the only key parameters affecting the nucleation events. Chemical compounds are needed in order to form a nucleus and contribute to subsequent growth of particles. Sulfuric acid is a 
key component in particle formation processes (Sipila et al., 2010). As regards $\mathrm{SO}_{2}$ concentrations, the regional (Fig. 3) and urban nucleation (Fig. 6) events at all monitoring sites (excluding the RS) exhibited low concentrations $(<1 \mathrm{ppb})$ suggesting the anthropogenic emissions affecting the study area were diluted by the windy Atlantic air mass scenarios (Fig. S4). Although such low concentrations could be sufficient to initiate nucleation, it is likely that other chemical components supported the new particle formation and growth. By contrast, the regional background nucleation event (Fig. 4) occurring only at the RB site was associated with a spike (2.1 ppb) of $\mathrm{SO}_{2}$ at 09:00 a.m. Due to low wind speed at the time, it is not possible to know if this $\mathrm{SO}_{2}$ plume originated from nearby industrial regions or from a $\mathrm{SO}_{2}$-enriched stable layer mixing downward with the morning evolution of the boundary layer.

Among the most cited mechanisms are binary (Vehkamaki et al., 2002) and ternary (Napari et al., 2002) nucleation. Laaksonen et al. (2009) reported that VOC oxidation products may also have a key role in determining the spatial and temporal features of nucleation events. The conclusion was supported by aircraft measurements, which showed that the nucleation events started in the surface layer, i.e. near the VOC source, and evolved together with the mixed layer. Lately, the role of organics in new particle formation has gained greater interest. Metzger et al. (2010) showed that the role of organics is important for the growth of the nucleated particles and for the nucleation itself. Riipinen et al. (2011) reported that the condensation of organic vapours is a crucial factor governing the lifetimes and the climatic importance of the smallest atmospheric particles.

Figures 1 and 5 are in line with the work of Reche et al. (2011) reporting UB ground level annual maximum $N$ at midday attributed to new particle formation. Additionally, our study suggests that the formation and/or growth of UF in urban nucleation events is enhanced in the vertical column above the city centre relative to the urban surface and the air column above the urban background. In other words, when considering all monitoring sites, the highest UF concentrations during NPF events are found above the city centre, in our case at $150 \mathrm{~m}$ a.s.l. The lifetimes of such particles depend on the competition between their condensational growth and cluster scavenging (directly proportional to the condensation sink - CS) (Kerminen and Kulmala, 2002). Boulon et al. (2010) surprisingly found a positive correlation between the NPF event frequency and the CS at elevated altitudes (Jungfraujoch, $3580 \mathrm{~m}$ a.s.l.), indicating that the vapour source of NPF is likely linked to polluted conditions and that at this site the presence of condensing vapours is a more important parameter for NPF to occur than a low CS. Nishita et al. (2008) also found nucleation mode particles in the mixed layer air, but never in the free tropospheric air, suggesting that new particle formation occurred in the air transported from the mixed layer. Because CS was consistently higher in the mixed layer air than in the free tropospheric air, the source rate of condensable vapors in the mixed layer air must be higher than that in the free tropospheric air, overcoming the inhibitory effects on NPF attributable to high CS.

In urban and suburban vertical air columns, traffic emissions are the dominant source of most volatile organic compounds (VOCs) to the atmosphere, with alkanes accounting for the largest contribution (Langford et al., 2010). Flocas et al. (2003) reported that at altitudes of 300-400 m, the VOC concentration levels remained high, suggesting the influence of surface sources. Additionally, it was found that the aromatic fraction gains significance with height as compared with the ground. By contrast, no differences were observed in the VOC concentrations within the $200 \mathrm{~m}$ layer above the ground due to the efficient vertical mixing (Velasco et al., 2008).

The relevance of organic compounds in aerosol formation was confirmed by both observation and simulated vertical profile of particle number concentrations during nucleation event days which showed a highly dynamical picture (Lauros et al., 2011). Furthermore, it was shown that deposition affects noticeably only the smallest particles in the lowest part of the atmospheric boundary layer. Primary aerosol sources can suppress nucleation through providing a condensation sink for sulfuric acid vapor and scavenging newly formed particles through increasing the coagulation sink.

If traffic related particles evaporate (Dall'Osto et al., 2011), then a source of VOC is provided in the urban air column, whilst the CS decreases with height (evaporation of primary particles and dilution of other sources i.e. terrestrial dust) as does temperature. Our study suggests that the lower CS found above the city as well as the additional availability of VOC possibly coming from traffic particles evaporation make an environment which favours the nucleation of particles.

\section{2 $\quad \mathrm{N} / \mathrm{BC}$ in relation to different variables}

Correlations between $\mathrm{BC}$ and $N$ are repeatedly observed in urban environments owing to the impact of vehicle exhaust emissions (Zhu et al., 2002; Rodriguez and Cuevas, 2007). However, whilst BC is an appropriate tracer for the intensity and proximity of traffic emissions (Turpin and Huntzicker, 1995), $N$ can also be affected by the occurrence of nucleation processes (Reche et al., 2011). Figure 7 investigates the correlations of $N$ versus BC at four different urban monitoring sites. It is important to bear in mind that the nucleation days were excluded from the current analysis, where such data would be confined in the top left part of the plots (high $N$ and low BC). The variation of $N / \mathrm{BC}$ with the following parameters is investigated; $\mathrm{NO}_{\mathrm{x}}$ (Fig. 7a), $\mathrm{RH}$ (Fig. 7b), temperature (Fig. 7c) and solar radiation (Fig. 7d). Fig. 7a shows a good linear correlation $\left(R^{2}=0.7-0.75\right)$ between $N$ and BC at the ground-level RS and UB sites, further supported by the correlation with $\mathrm{NO}_{\mathrm{x}}$ presented in the colour plot and implying a direct traffic source of $\mathrm{N}$. In contrast, the $N / \mathrm{BC}$ 

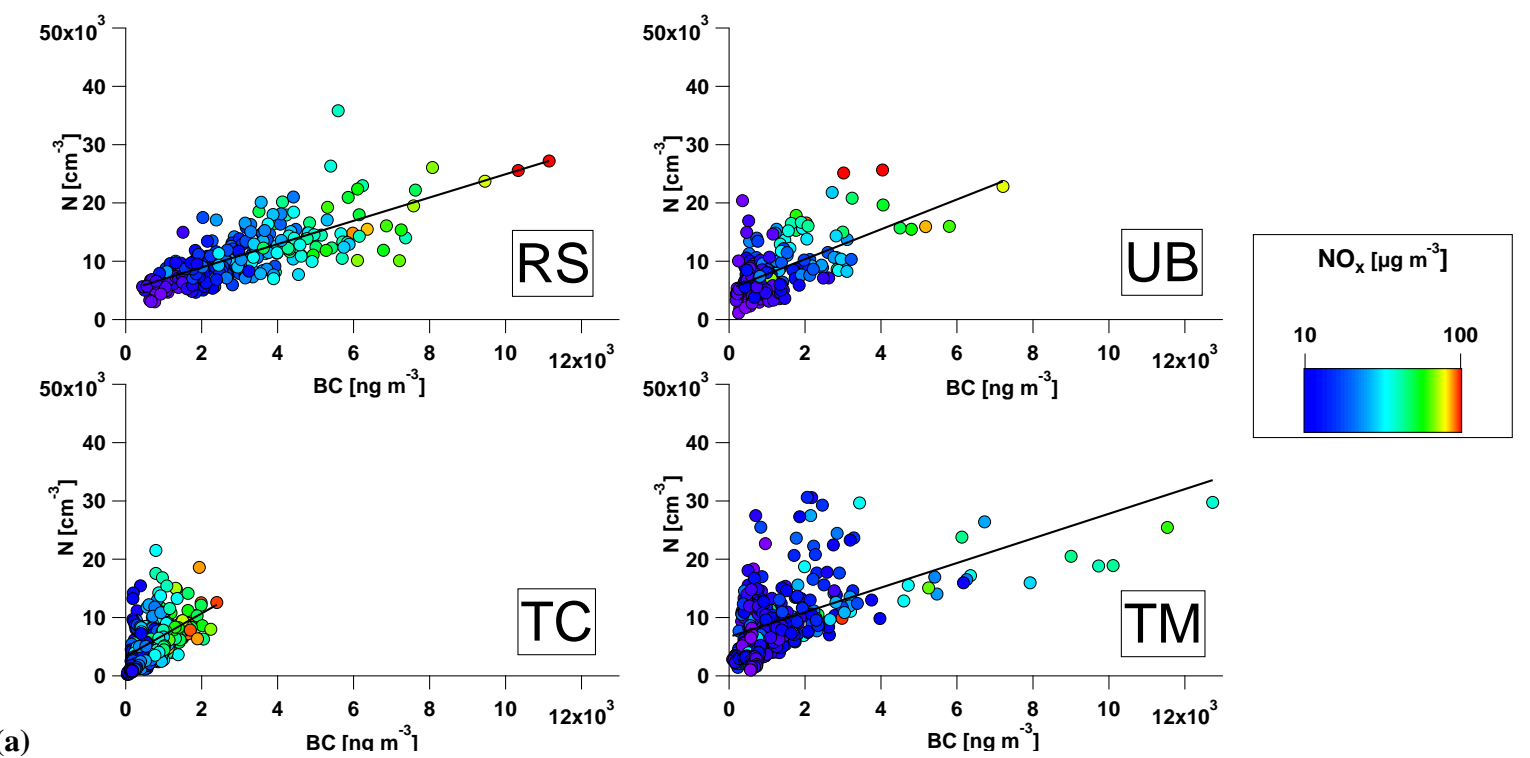

(a)
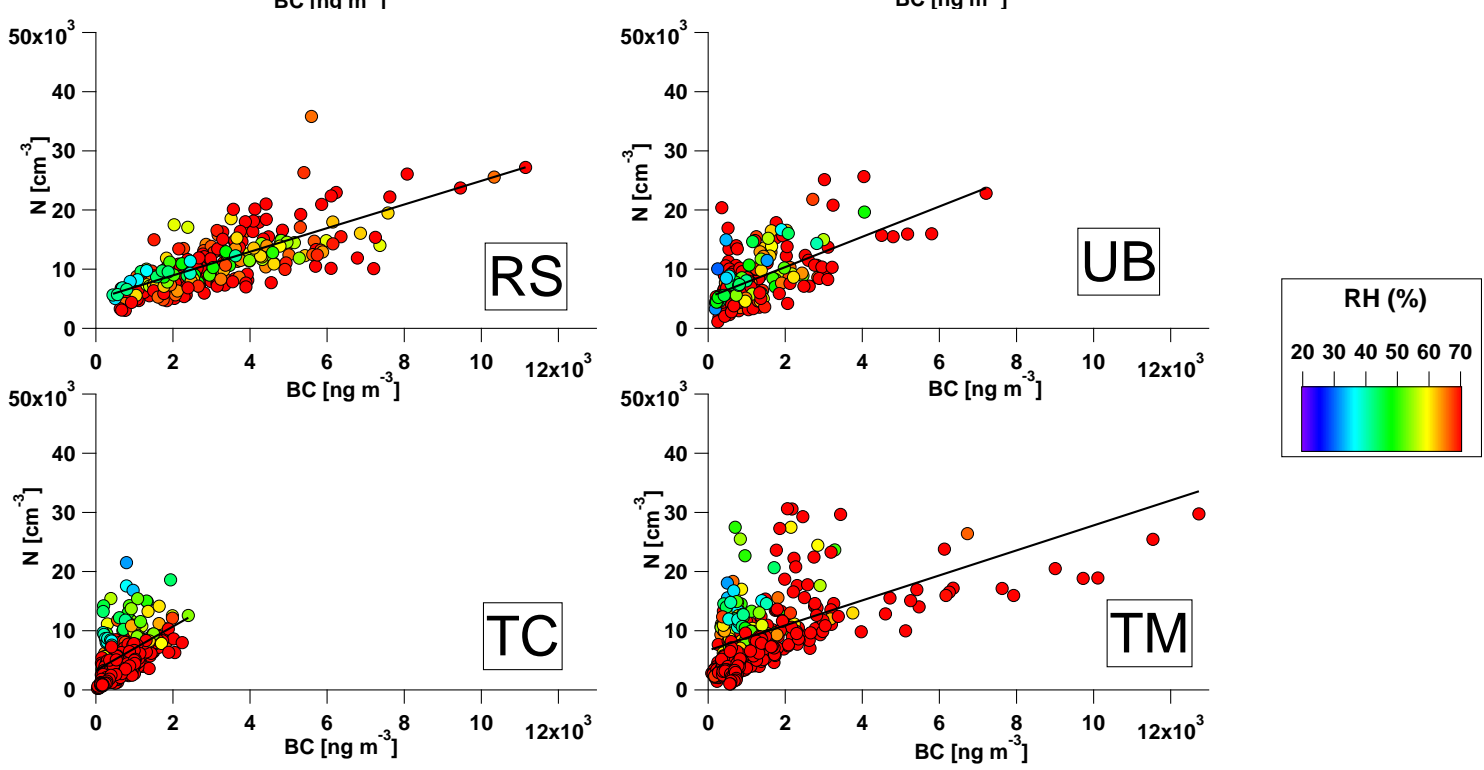

(b)

Fig. 7. Hourly black carbon $(\mathrm{BC})$ and particle number concentrations $(N)$ at four different monitoring sites. In contour plots are shown (a) $\mathrm{NO}_{\mathrm{x}}$, (b) RH.

plots for the two tower sites (TM and TC) suggest a linear correlation between $N$ and $\mathrm{BC}$ only where a $\mathrm{NO}_{\mathrm{x}}$ dependency is also found. In other words, there is a large ensemble of points to the top left part of the $N / \mathrm{BC}$ diagram for TC and $\mathrm{TM}$, indicating higher $N / \mathrm{BC}$ ratios not correlated with $\mathrm{NO}_{\mathrm{x}}$ (blue points) and suggesting an additional source of UF particles at the tower sites (TM, TC) but not at the ground sites (UB, RS). Further differences between the ground sites (RS, UB) and the tower ones (TC, TM) should be noted in Fig. 7b. Whilst the ground sites do not have a clear RH dependency, the tower sites possess the highest $N / \mathrm{BC}$ ratios (top left part of the plot) associated with the driest conditions (blue and green points). An even clearer gradient is seen at all sites when temperature values are considered (Fig. 7c), with higher $N / \mathrm{BC}$ recorded with the highest temperatures. However, the correlation between the N/BC plot and temperature at the road site is surprising. Previous studies (Olivares et al., 2007) reported an increase in $N$ with decreasing temperature in a street canyon in Stockholm. Bigi and Harrison (2010) also found $N$ showing a minimum corresponding with maximum air temperatures in August in London, consistent with loss of nanoparticle by evaporation during atmospheric transport. In this work we find opposite trends: for a given $\mathrm{BC}$ concentration, higher $N$ are recorded with higher temperature, implying that other sources of UF particles are impacting the RS monitoring site. Finally, Fig.7d shows the $N / \mathrm{BC}$ plot as function of solar radiation. It shows an unclear dependence for the ground sites UB and RS, (but data for the 

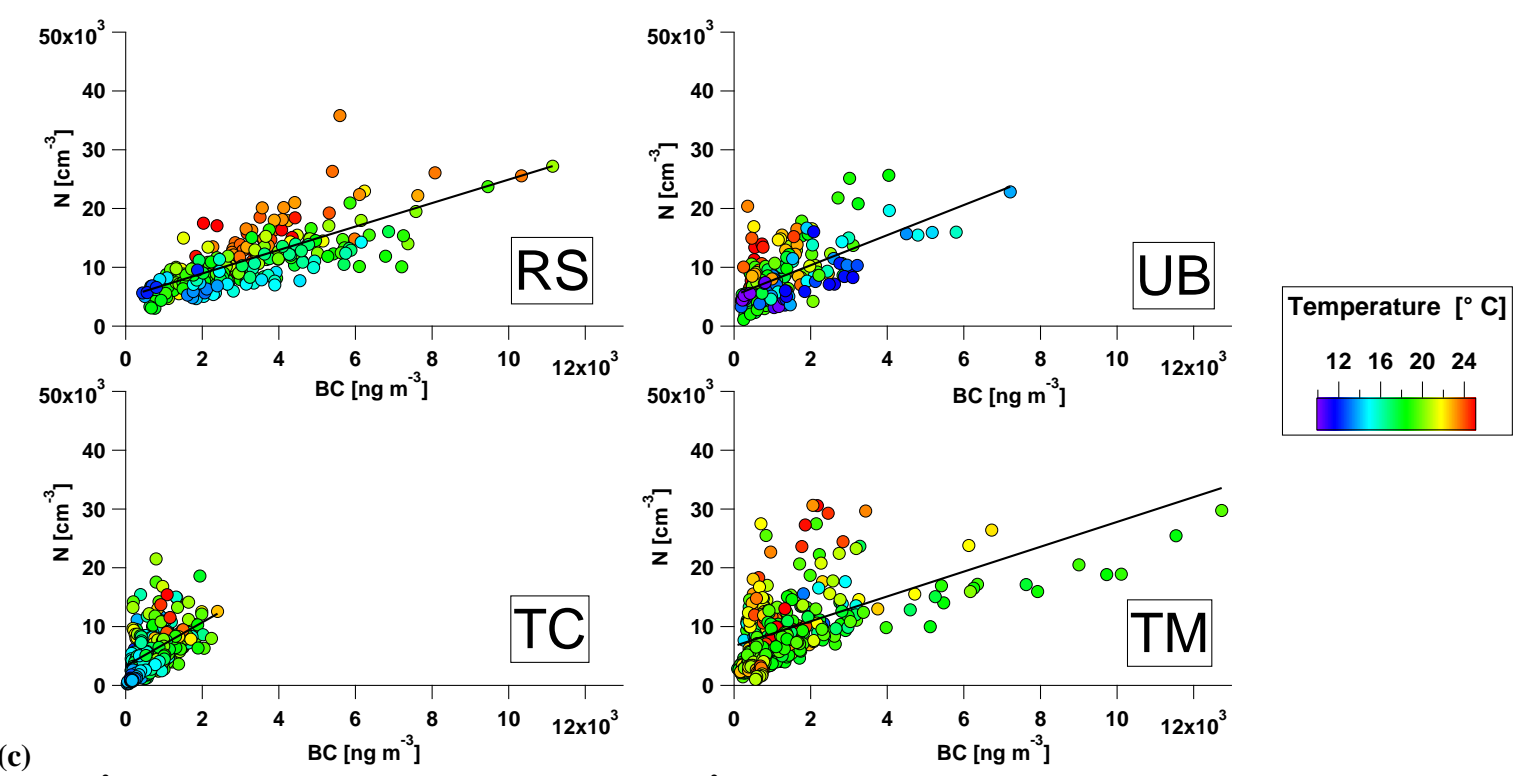

(c)
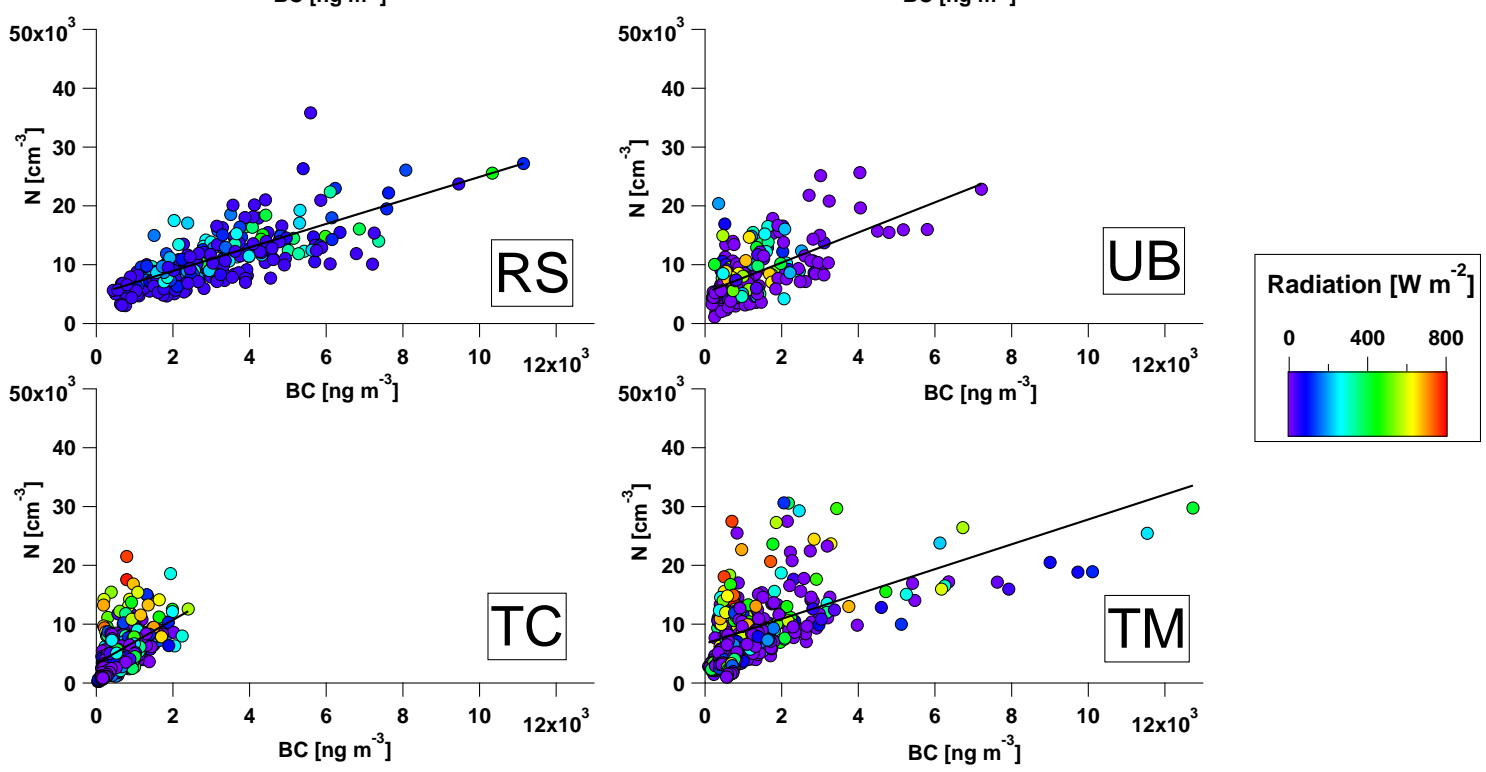

(d)

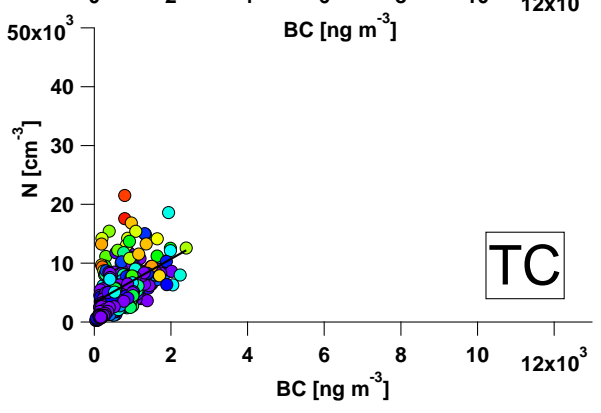

Fig. 7. Hourly black carbon $(\mathrm{BC})$ and particle number concentrations $(N)$ at four different monitoring sites. In contour plots are shown (c) temperature and $(\mathbf{d})$ radiation values.

latter were compromised by shadows of nearby buildings), but a strong gradient for the two tower sites (TM, TC) with high solar radiation values found above the intercept $N / \mathrm{BC}$.

In summary, $N$ and $\mathrm{BC}$ seem linearly correlated at all sites only when there is also a $\mathrm{NO}_{\mathrm{x}}$ correlation with them. However, we find that the N/BC plots diverge from linearity towards higher values (top left part of the diagram, Fig. 7) when primary traffic conditions (high values of $\mathrm{BC}$ ) are not the only determining factor. A strong dependence upon $\mathrm{RH}$ and radiation values for the two towers and strong temperature dependence for all ground and tower sites should also be kept in mind. Figure 8 shows the regression lines between $N$ and BC for the four urban sites, excluding days of regional and urban nucleation events (25 September, 5 October and 17 October 2010). It is important to note that only the urban sites (RS, UB, TM, TC) are considered in this analysis, as the main objective is to study the relationship between $N$ and $\mathrm{BC}$ in the urban atmosphere. Fair to good linear correlations are found $\left(R^{2}=0.41-0.77\right)$. The intercept gives an indication of the non traffic contribution (BC $=0$ ), whereas the gradient reflects a contribution from local traffic sources. The highest intercept is found for the urban tower TM $\left(6700 \mathrm{~cm}^{-3}\right)$ whereas the lowest one is associated with the urban background tower TC $\left(3700 \mathrm{~cm}^{-3}\right)$. This indicates that highest background particle number concentrations are seen above the urban tower (TM) in the city centre. 


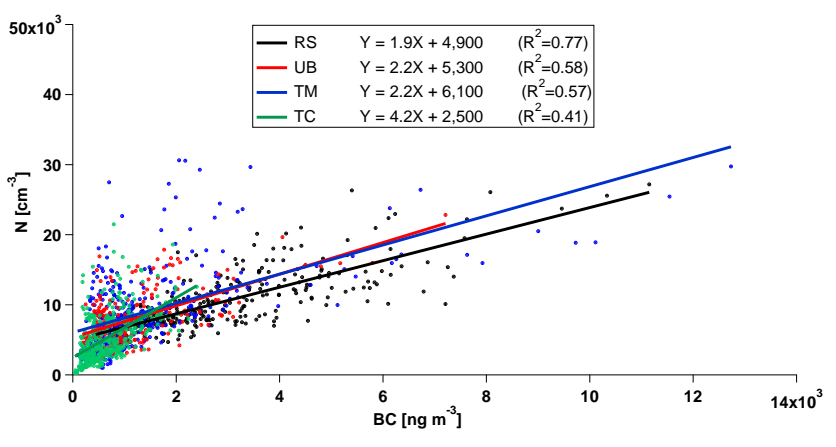

Fig. 8. Linear correlations between $\mathrm{BC}$ and $N$ at four different monitoring sites. Note that data of the three nucleation event days (regional and urban) are not included in the chart.

However, those concentrations become lower when sampling aerosols at tower level but away from the urban city agglomerate (TC). Whilst $N$ correlates linearly very well with BC at the RS site, the correlations for the other three sites away from traffic hot spots are not so good. This is particularly well seen for the two tower sites (TM, TC), where a number of points are found at low BC concentrations $\left(<4 \mu \mathrm{g} \mathrm{m}^{-3}\right)$ but high $N\left(>10000 \mathrm{~cm}^{-3}\right)$. By individually inspecting the occurrence of such hourly data points, we found that those are mainly associated with afternoon values on 24,26 and 27 September 2010. Such days are characterised by similar marine Polar conditions found for the regional nucleation events (25 September 2010), implying that a burst of UF particles was recorded at higher level (TC, TM) but could not be clearly monitored by the CPC or SMPS instruments deployed at ground level (RS, UB). Given the high variability of the scatter plot seen in Fig. 8, the regression lines were calculated separately for each hour of the day for each sampling site (96 regression lines, Fig. S7). Fig. S8 shows the results grouped in 4 time intervals: 00:00-06:00, 06:00-12:00, 12:00-18:00 and 18:00-00:00.

The RS gives an intercept at about 6000 particles $\mathrm{cm}^{-3}$, with a reduction of about $25 \%$ during morning rush hour. This could be interpreted as higher CS due to fresh primary particles emitted and reducing the background concentrations. The TM and UB site seems to follow a similar pattern, with higher $N$ concentrations during day time. However, it is important to note that all sites present roughly the same regional $N$ concentration at about $6000 \mathrm{~cm}^{-3}$ during afternoon time when the boundary layer is fully developed. Much more difficult is to interpret the gradient, which should give a contribution of the primary particles linked to the BC. With this assumption, Table 2 shows that under clean conditions (mP air masses), at the road site RS $28 \%$ are primary (but they reach $37 \%$ during rush hours), whereas during polluted conditions (mC air masses) higher values are seen (47\%, up to $58 \%$ during morning rush hours). By contrast, the urban tower TM sees similar conditions for the UB site: more primary particles during night time but the least during morning
Table 2. Percentage (\%) of primary traffic particles (EC related) at different time of the day under polluted conditions (cP air masses) and diluted Atlantic conditions ( $\mathrm{mP}$ air masses) at four different monitoring sites.

\begin{tabular}{|c|c|c|c|c|c|}
\hline \multicolumn{2}{|c|}{$\begin{array}{c}\% \text { Traffic Primary particles } \\
\text { (mP air masses) }\end{array}$} & RS & UB & $\mathrm{TM}$ & $\mathrm{TC}$ \\
\hline \multirow{4}{*}{$\begin{array}{l}\text { Hour of } \\
\text { the day }\end{array}$} & 0 & 20 & 20 & 41 & 50 \\
\hline & 6 & 37 & 18 & 24 & 42 \\
\hline & 12 & 30 & 11 & 35 & 9 \\
\hline & 18 & 24 & 13 & 20 & 15 \\
\hline \multicolumn{2}{|c|}{$\begin{array}{c}\% \text { Traffic Primary particles } \\
\text { (cP air masses) }\end{array}$} & $\mathrm{RS}$ & UB & $\mathrm{TM}$ & $\mathrm{TC}$ \\
\hline \multirow{4}{*}{$\begin{array}{l}\text { Hour of } \\
\text { the day }\end{array}$} & 0 & 37 & 51 & 51 & 71 \\
\hline & 6 & 58 & 46 & 33 & 64 \\
\hline & 12 & 50 & 32 & 45 & 20 \\
\hline & 18 & 42 & 38 & 48 & 30 \\
\hline
\end{tabular}

rush hours. The overall resulting scenario is a large proportion of particles not associated with EC traffic particles (seen also in Fig. S9).

Figure 9 summarises the overall structure of $N$ versus BC at the 4 monitoring sites. The road site shows a flat line with a ratio of about $4 \mathrm{~cm}^{-3} \mathrm{ng} \mathrm{m}^{-3}$ for most of the day, with a slight increase at 14:00-15:00, indicating a contribution of new particle formation (higher $N / \mathrm{BC}$ ) during the warmer part of the day. The UB site shows a similar feature, but a much enhanced N/BC ratio in the afternoon. The two towers show a similar trend, but different from the ground-level sites. A lower ratio is seen at TC and TM for the morning rush hour. This cannot be explained by dilution as when the boundary layer develops, both $\mathrm{BC}$ and $N$ should dilute, leading us to suggest some particles may evaporate (leading to a lower $N / \mathrm{BC}$ ) when the atmosphere starts to heat up in the morning. In other words, a reduction of the ratio N/BC (07:00-10:00 at TC and TM, Fig. 8) can be explained by some semi-volatile particles evaporating when the urban heat begins to develop. An alternative explanation is that an overnight atmosphere with a high $N / \mathrm{BC}$ ratio is mixed with fresh traffic emissions with lower $N / \mathrm{BC}$ ratio. During afternoon, more particles are seen at both towers, higher than at the ground site. This is an indication that nucleation processes are taking place above the city in the afternoon at higher intensity than ground-level. However, this process is confined to the area above the city centre as when we move away from the TM and arrive at the urban background tower TC, this is reduced (Fig. 9).

\section{Discussion and conclusion}

Within the SAPUSS project, the sources and the evolutions of UF particles were investigated both horizontally and vertically in the large urban agglomerate of Barcelona, Spain. 


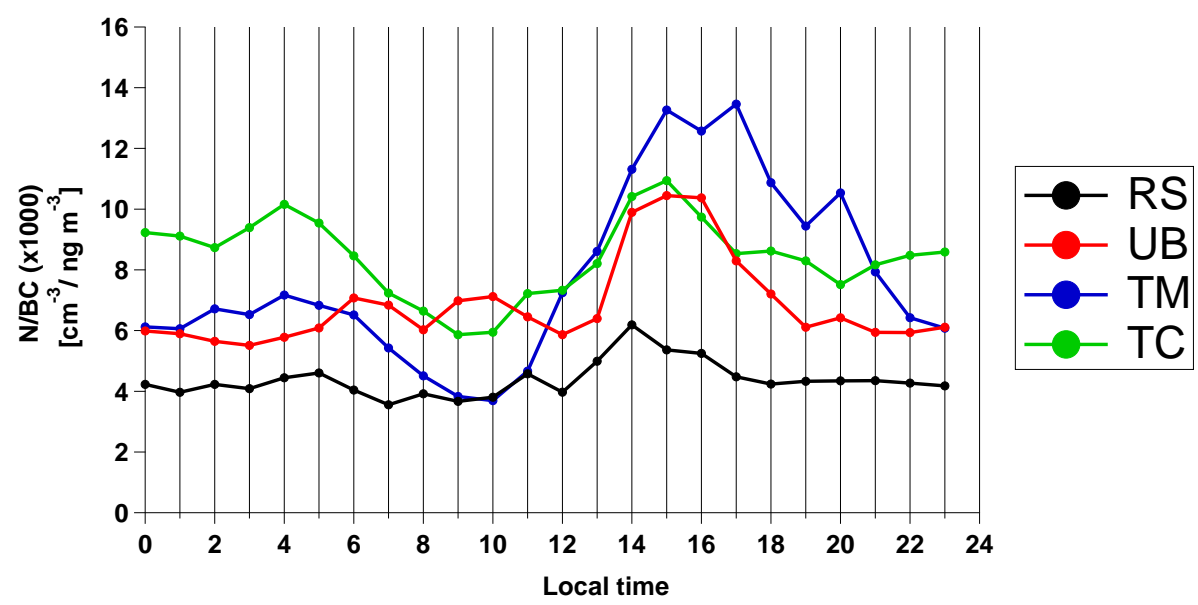

Fig. 9. Diurnal variation of the $N / \mathrm{BC}$ ratio at four different monitoring sites.

Ground- level measurements were taken in the city centre hot spot as well as in the urban and regional background. Furthermore, two towers were also used as monitoring stations: Tower Mapfre (TM, $150 \mathrm{~m}$ above ground, $150 \mathrm{~m}$ a.s.l.) located in the city centre, and Tower Collserola (TC, 80 $\mathrm{m}$ above ground, $525 \mathrm{~m}$ a.s.1.), located in the hills bounding the urban agglomeration. Our results show that, under stagnant polluted atmospheric conditions, primary traffic particles are the main source of $N$ and $\mathrm{BC}$, with clear vertical and horizontal concentrations gradients decreasing with the distance from the traffic city centre hot spot. By contrast, under cleaner conditions (marine Polar air masses, high wind speed and low condensation sinks), the sources and evolutions of UF particles become more complex:

- A regional nucleation event (Fig. 3) can impact the whole region, including the city centre. Such nucleation events begin in the morning at about 09:00-11:00 and are found with the passage of a new cold dry Atlantic front.

- A second regional background nucleation event (Fig. 4) can impact only the background region, excluding the city centre and the urban background. Such nucleation event are also found with the passage of a new cold dry Atlantic front, beginning in the morning (09:00 UTC) and, in the one case identified, associated with an elevated $\mathrm{SO}_{2}$ concentration.

- A third more city-localised type of nucleation event can originate in the city centre. In this case, $N$ is found to have the highest concentrations at 14:00-15:00 at all monitoring sites, where the $\mathrm{BC}$ is at its lowest levels. Additionally, we find higher $N$ above the city centre vertical column rather than on the ground. This type of nucleation event is associated with particle growth while being transported away towards the regional background, reaching $\mathrm{CCN}$ sizes.
This study suggests that, under sunny, dry and low CS atmospheric conditions, volatility of traffic related particles is driving not only the loss of themselves (by evaporation) but at the same time it could provide additional VOC material in the atmosphere. As pointed out by Kulmala and Kerminen (2008), high vapour source rate and the low CS due to pre-existing particles are the two most important parameters governing new particle formation. We speculate that organic compounds evaporating from freshly emitted traffic particles are possible candidates for new particle formation above the urban surface. In other words, our study suggests that the column of air above the city ground level possesses the best combination of low CS and high vapour source, hence enhancing the concentrations of freshly nucleated particles.

Taking the same approach used by Stanier et al. (2004), Fig. 10 summarises our findings by showing the correlation between the product of [UV intensity $* \mathrm{SO}_{2}$ concentration] (a proxy for sulfuric acid production) versus the condensational sink calculated for four different monitoring sites (RS: black; UB: red; TCg: blue; RB: green). The empty dots correspond to periods when a nucleation event is not observed. The regional nucleation events are shown with triangle markers (regional nucleation, 25/09/2010) and square markers (regional background nucleation only, 17/10/2010). By contrast, the urban nucleation event $(05 / 10 / 2010)$ is shown with full dots. The 45 degree line roughly divides each plot into two regions - the upper left region where nucleation is generally observed in urban areas (blue, red and black - TC, UB, RS), and the lower right region where nucleation is more common in the regional background area (green points, RB). The conclusions that can be drawn from comparing the different nucleation events presented in Fig. 10 are as follows: for a given level of pre-existing aerosol surface area (CS) and a given level of solar irradiance (UV), nucleation events occurring in the urban area require a lower level of $\mathrm{SO}_{2}$ concentration than events occuring in a regional background area. Hence, additional factors such as traffic organic compounds 


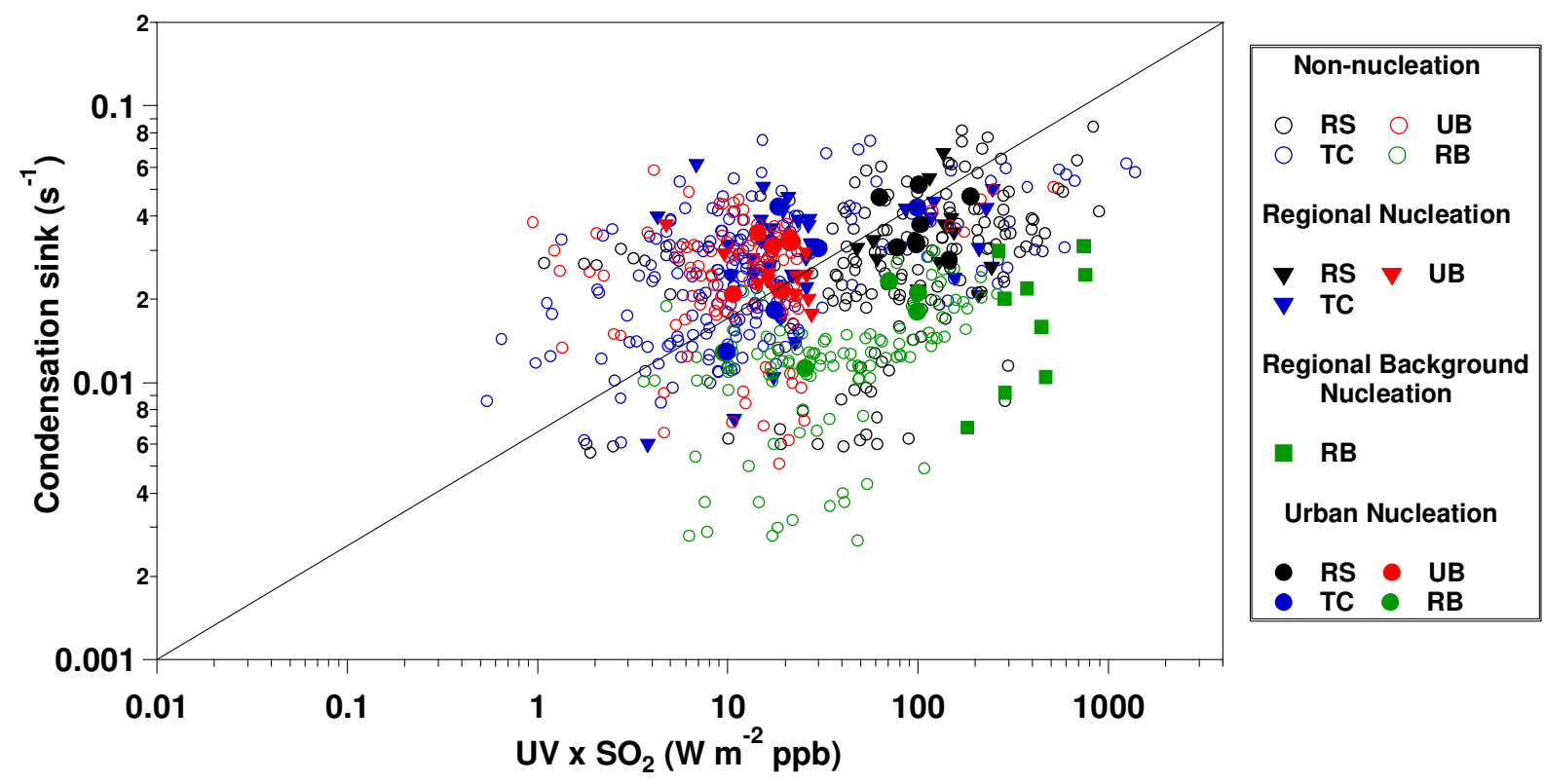

Fig. 10. Correlation showing [ $\left.\mathrm{UV} \times \mathrm{SO}_{2}\right]$ versus condensational sink for four different monitoring sites (RS: black; UB: red; TC: blue; RB: green). One hour averaged values are plotted for all time periods of the study. Empty dots: non nucleation hours. Full dots: urban nucleation event. Square markers: regional background nucleation event. Triangle markers: regional nucleation event.

are likely to be involved in the nucleation events originating in urban areas.

Model simulations indicate that nucleation is a significant source of aerosol particles in the global atmosphere (Spracklen et al., 2008). The importance of secondary particle formation on a global scale is uncertain, though it may make a significant contribution to both global condensation nuclei $(\mathrm{CN})$ and cloud condensation nuclei $(\mathrm{CCN})$ concentrations (Spracklen et al., 2008; Spracklen et al., 2010). Reddington et al. (2011) recently quantified how primary particle emissions and secondary particle formation influence size-resolved particle number concentrations in the boundary layer by using a global aerosol microphysics model as well as aircraft and ground site observations. It was found that the major source of uncertainty in CCN-sized particles in polluted European air is the emitted size of primary carbonaceous particles. It is important to understand the relative contribution of primary and secondary particles to regional and global aerosol so that models can attribute aerosol radiative forcing to different sources. This study suggests that, within the urban atmosphere, freshly emitted primary traffic particles can convert into freshly nucleated secondary particles under certain conditions, leading to very complex aerosol dynamics.

Supplementary material related to this article is available online at: http://www.atmos-chem-phys.net/13/ 741/2013/acp-13-741-2013-supplement.pdf.
Acknowledgements. FP7-PEOPLE-2009-IEF, Project number 254773, SAPUSS - Solving Aerosol Problems Using Synergistic Strategies (Marie Curie Actions - Intra European Fellowships. Manuel Dall'Osto). This study was previously supported by research projects from the D.G. de Calidad y Evaluacion Ambiental (Spanish Ministry of the Environment) and the Plan Nacional de I p D (Spanish Ministry of Science and Innovation CGL2010-19464 (VAMOS), and the Departaments of Medi Ambient from the Generalitat de Catalunya and Diputacio of Barcelona who kindly supported data of gaseous pollutants. ACTRIS is also acknowledged for aerosol size distributions at the RB site. Meteorological data were provided by the Servei Meteorológic de Catalunya and by the Department of Physics from the University of Barcelona. Santiago Castante (Mapfre Tower), Diego Garcia Talavera (Collserola tower) and Alfons Puertas (Secció de Meteorologia, Fabra obstervatory) are also acknowledged. The SAPUSS team is finally acknowledged, in particular Michael Cusack, María-Cruz Minguillón and Johanna Gietl.

Edited by: S. Decesari

\section{References}

Aalto, P., Hämeri, K., Paatero, P., Kulmala, M., Bellander, T., Berglind, N., Bouso, L., Castano-Vinyals, G., Jordi Sunyer, J., Cattani, G., Marconi, A., Cyrys, J., von Klot, S., Peters, A., Zetzsche, K., Lanki, T., Pekkanen, J., Nyberg, F., Sjövall, B., and Forestiere, F.: Aerosol particle number concentration measurements in five European cities using TSI-3022 condensation particle counter over a three-year period during health effects of air pollution on susceptible subpopulations, J. Air Waste Manage. Assoc., 55, 1064-1076, 2005. 
Alam, A., Shi, J. P., and Harrison, R. M.: Observations of new particle formation in urban air, J. Geophys. Res., 108, 4093, doi:10.1029/2001JD001417, 2003.

Bigi, A.; Harrison, R. M.; Analysis of the air pollution climate at a central urban background site, Atmos. Environ., 44, 2004-2012, doi:10.1016/j.atmosenv.2010.02.028, 2010

Birmili W., Wiedensholer, A., Heintzenberg, J., and Lehmann, K.: Atmospheric particle number size distribution in central europe: statistical relations to air masses and meteorology, J. Geophys. Res., 106, 32005-32018, 2001.

Boulon, J., Sellegri, K., Venzac, H., Picard, D., Weingartner, E., Wehrle, G., Collaud Coen, M., Bütikofer, R., Flückiger, E., Baltensperger, U., and Laj, P.: New particle formation and ultrafine charged aerosol climatology at a high altitude site in the Alps (Jungfraujoch, $3580 \mathrm{~m}$ a.s.1., Switzerland), Atmos. Chem. Phys., 10, 9333-9349, doi:10.5194/acp-10-9333-2010, 2010.

Boulon, J., Sellegri, K., Hervo, M., Picard, D., Pichon, J.-M., Fréville, P., and Laj, P.: Investigation of nucleation events vertical extent: a long term study at two different altitude sites, Atmos. Chem. Phys., 11, 5625-5639, doi:10.5194/acp-11-56252011, 2011.

Charron, A. and Harrison, R. M.: Primary particle formation from vehicle emissions during exhaust dilution in the roadside atmosphere, Atmos. Environ., 37, 4109-4119, 2003.

Cheung, H. C., Morawska, L., and Ristovski, Z. D.: Observation of new particle formation in subtropical urban environment, Atmos. Chem. Phys., 11, 3823-3833, doi:10.5194/acp-11-38232011, 2011.

Crumeyrolle, S., Manninen, H. E., Sellegri, K., Roberts, G., Gomes, L., Kulmala, M., Weigel, R., Laj, P., and Schwarzenboeck, A.: New particle formation events measured on board the ATR-42 aircraft during the EUCAARI campaign, Atmos. Chem. Phys., 10, 6721-6735, doi:10.5194/acp-10-6721-2010, 2010

Dall'Osto, M., Thorpe, A., Beddows, D. C. S., Harrison, R. M., Barlow, J. F., Dunbar, T., Williams, P. I., and Coe, H.: Remarkable dynamics of nanoparticles in the urban atmosphere, Atmos. Chem. Phys., 11, 6623-6637, doi:10.5194/acp-11-66232011, 2011.

Dall'Osto, M, A. Alastuey, M. A. Pedemonte, B. L. van Drooge, M. Pandolf, M. C. Minguillo, F. Amato, T. Moreno, J. Pey, C. Reche, M. Cusak, M. Viana, A. Roca, J . Gietl, D. Beddows, Roy M. Harrison, J. Wenger, E. McGillicuddy, J. Sodeau, R. Healy, D. Ceburnis, G. Martucci, C. O’Dowd, F. Lucarelli, S. Nava, J. L. Jimenez, F. Gomez Moreno, B. Artinono, A. S. H. Prévôt, L. Pfaffenberger, S. Frey, F. Wilsenack, S. Ng, D. Worsnop, D. Casabona Fina, P. Jiménez Guerrero, X. Querol - Presenting SAPUSS: Solving Aerosol Problems by Using Synergistic Strategies, this issue Atmos. Chem. Phys. Discuss., 2012a.

Dall'Osto, M., Beddows, D. C. S., Pey, J., Rodriguez, S., Alastuey, A., Harrison, Roy M., and Querol, X.: Urban aerosol size distributions over the Mediterranean city of Barcelona, NE Spain, Atmos. Chem. Phys., 12, 10693-10707, doi:10.5194/acp-1210693-2012, 2012b.

Dal Maso, M., Kulmala, M., Riipinen, I., Wagner, R., Hussein, T., Aalto, P. P., and Lehtinen, K. E. J.: Formation and growth of fresh atmospheric aerosols: eight years of aerosol size distribution data from SMEAR II, Hyytiala, Finland, Boreal Environ. Res., 10, 323-336, 2005
Davidson, C., Phalen, R., and Solomon, P.: Airborne particulate matter and human health: a review, Aerosol Sci. Technol., 39, 737-749, 2005.

Flocas, H. A., Assimakopoulos, V. D., and Helmis, C. G.: VOC and $\mathrm{O}_{3}$ distribution over the densely populated area of Greater Athens, Greece. J. Appl. Meteorol. 1799-1810, 2003.

Haeffelin M., Angelini F., Morille Y., Martucci G., Frey S., Gobbi G. P., Lolli S., O’Dowd C. D., Sauvage L., Xueref-Remy I., and Wastine B.: Evaluation of mixing height retrievals from automatic profiling lidars and ceilometers in view of future integrated networks in Europe, Bound.-Lay. Meteorol., 1-27. doi:10.1007/s10546-011-9643-z, 2011

Hamburger, T., McMeeking, G., Minikin, A., Birmili, W., Dall'Osto, M., O’Dowd, C., Flentje, H., Henzing, B., Junninen, H., Kristensson, A., de Leeuw, G., Stohl, A., Burkhart, J. F. Coe, H., Krejci, R., and Petzold, A.: Overview of the synoptic and pollution situation over Europe during the EUCAARILONGREX field campaign, Atmos. Chem. Phys., 11, 10651082, doi:10.5194/acp-11-1065-2011, 2011.

Hamed, A., Korhonen, H., Sihto, S.-L., Joutsensaari, J., Jarvinen, H., Petaja, T., Arnold, F., Nieminen, T., Kulmala, M., Smith, J. N., Lehtinen, K. E. J., and Laaksonen, A.: The role of relative humidity in continental new particle formation, J. Geophys. Res., 116, D03202, doi:10.1029/2010JD014186, 2011.

Harrison, R. M. and Yin, J.: Particulate matter in the atmosphere: which particle properties are important for its effects on health?, Atmos. Environ., 85-101, 2000.

Harrison, R. M., Shi, J. P., Xi, S. H., Khan, A., Mark, D., Kinnersley, R., and Yin, J. X.: Measurement of number, mass and size distribution of particles in the atmosphere, Phil. Trans. Roy. Soc. Ldn. Ser. A Math. Phys. Eng. Sci., 358, 2567-2579, 2000.

Harrison, R. M., Beddows, D. C. S., and Dall'Osto, M.: PMF Analysis of wide-range particle size spectra collected on a major highway, Environ. Sci. Technol., 45, 5522-5528, 2011.

Harrison, R. M., Dall'Osto, M., Beddows, D. C. S., Thorpe, A. J., Bloss, W.J., Allan, J. D., Coe, H., Dorsey, J. R., Gallagher, M., Martin, C., Whitehead, J., Williams, P. I., Jones, R. L., Langridge, J. M., Benton, A. K., Ball, S. M., Langford, B., Hewitt, C. N., Davison, B., Martin, D., Petersson, K., Henshaw, S. J., White, I. R., Shallcross, D. E., Barlow, J. F., Dunbar, T., Davies, F., Nemitz, E., Phillips, G. J., Helfter, C., Di Marco, C. F., and Smith, S.: Atmospheric chemistry and physics in the atmosphere of a developed megacity (London): An overview of the REPARTEE experiment and its conclusions, Atmos. Phys. Chem., 12, 3065-3114, doi:10.5194/acp-12-3065-2012, 2012.

Heese, B., Flentje, H., Althausen, D., Ansmann, A., and Frey, S.: Ceilometer-lidar inter-comparison: backscatter coefficient retrieval and signal-to-noise ratio determination, Atmos. Meas. Tech., 3, 1763-1770, doi:10.5194/amt-3-1763-2012, 2010.

Hitchins, J., Morawska, L., Gilbert, D., and Jamriska, M.: Dispersion of particles from vehicle emissions around high- and lowrise buildings, Ind. Air, 12, 64-71, 2002.

Hussein, T., Junninen, H., Tunved, P., Kristensson, A., Dal Maso, M., Riipinen, I., Aalto, P. P., Hansson, H.-C., Swietlicki, E., and Kulmala, M.: Time span and spatial scale of regional new particle formation events over Finland and Southern Sweden, Atmos. Chem. Phys., 9, 4699-4716, doi:10.5194/acp-9-4699-2009, 2009

Jaenisch, V., Stratmann, F., Austin, P. H., and Hegg, D. A.: Influence of turbulent mixing processes on new particle formation: First 
results, J. Aerosol Sci., 28, Suppl. 1, S27-S28, 1997.

Jeong, C.-H., Evans, G. J., McGuire, M. L., Chang, R. Y.-W., Abbatt, J. P. D., Zeromskiene, K., Mozurkewich, M., Li, S.-M., and Leaitch, W. R.: Particle formation and growth at five rural and urban sites, Atmos. Chem. Phys., 10, 7979-7995, doi:10.5194/acp10-7979-2010, 2010.

Kerminen, V.-M. and Kulmala, M.: Analytical formulae connecting the "real" and the "apparent" nucleation rate and the nuclei number concentration for atmospheric nucleation events, J. Aerosol Sci., 33, 609-622, 2002.

Khosrawi, F. and Konopka, P.: Enhanced particle formation and growth due to mixing processes in the tropopause region, Atmos. Environ., 37, 903-910, 2003.

Kulmala, M. and Kerminen, V.-M.: On the growth of atmospheric nanoparticles, Atmos. Res., 90, 132-150, 2008.

Kulmala, M., Dal Maso, M., Mäkelä, J. M., Pirjola, L., Väkevä, M., Aalto, P., Miikkulainen, P., Hämmeri, K., and O'Dowd, C.: On the formation, growth and composition of nucleation mode particles, Tellus, 53B, 479-490, 2001.

Kulmala, M., Vehkamäki, H., Petäjä, T., Dal Maso, M., Lauri, A., Kerminen, V.-M., Birmili, W., and McMurry, P. H.: Formation and growth rates of ultrafine atmospheric particles: A review of observations, J. Aerosol Sci., 35, 143-176, 2004.

Kumar, P., Fennell, P., Hayhurst, A. N., and Britter, R. E.: Street versus rooftop level concentrations of fine particles in a Cambridge street canyon, Bound.-Lay. Meteorol., 131, 3-18, 2009.

Laaksonen, A., Kulmala, M., O’Dowd, C. D., Joutsensaari, J., Vaattovaara, P., Mikkonen, S., Lehtinen, K. E. J., Sogacheva, L., Dal Maso, M., Aalto, P., Petäjä, T., Sogachev, A., Yoon, Y. J., Lihavainen, H., Nilsson, D., Facchini, M. C., Cavalli, F., Fuzzi, S., Hoffmann, T., Arnold, F., Hanke, M., Sellegri, K., Umann, B., Junkermann, W., Coe, H., Allan, J. D., Alfarra, M. R., Worsnop, D. R., Riekkola, M. -L., Hyötyläinen, T., and Viisanen, Y.: The role of VOC oxidation products in continental new particle formation, Atmos. Chem. Phys., 8, 2657-2665, doi:10.5194/acp-82657-2008, 2009

Langford, B., Nemitz, E., House, E., Phillips, G. J., Famulari, D., Davison, B., Hopkins, J. R., Lewis, A. C., and Hewitt, C. N.: Fluxes and concentrations of volatile organic compounds above central London, UK, Atmos. Chem. Phys., 10, 627-645, doi:10.5194/acp-10-627-2010, 2010

Lauros, J., Sogachev, A., Smolander, S., Vuollekoski, H., Sihto, S.L., Mammarella, I., Laakso, L., Rannik, Ü., and Boy, M.: Particle concentration and flux dynamics in the atmospheric boundary layer as the indicator of formation mechanism, Atmos. Chem. Phys., 11, 5591-5601, doi:10.5194/acp-11-5591-2011, 2011

Li, X. L.,Wang, J. S., Tu, X. D., Liu, W., and Huang, L.: Vertical variations of particle number concentration and size distribution in a street canyon in Shanghai, China, Sci. Total Environ., 378, 306-316, 2007

Longley, I. D., Gallagher, M. W., Dorsey, J. R., Flynn, M., Allan, J. D., Alfarra, M. R., and Inglis, D.: A case study of aerosol $\left(4.6 \mathrm{~nm}<D_{\mathrm{p}}<10 \mu \mathrm{m}\right)$ number and mass size distribution measurements in a busy street canyon in Manchester, UK, Atmos. Environ., 37, 1563-1571, 2003.

Martin, C. L., Longley, I. D., Dorsey, J. R., Thomas, R. M., Gallagher, M. W., and Nemitz, E.: Ultrafine particle fluxes above four major European cities, Atmos. Environ., 43, 4714-4721, 2009.
Martucci, G., Milroy, C., and O'Dowd, C. D.: Detection of Cloud Base Height Using Jenoptik CHM15K and Vaisala CL31 Ceilometers, J. Atmos. Ocean. Technol., 27, 305-318, 2010.

McMurry, P. H., Woo, K. S., Weber, R., Chen, D.-R., and Pui, D. Y.: Size distributions of 3-10 nm atmospheric particles: Implications for nucleation mechanisms, Philos. Trans. R. Soc. Ldn., Ser. A, 358, 2625-2642, 2000.

Metzger, A., Verheggen, B., Dommen, J., Duplissy, J., Prevot, A. S. H., Weingartner, E., Riipinen, I., Kulmala, M., Spracklen, D. V., Carslaw, K. S., and Baltensperger, U.: Evidence for the role of organics in aerosol particle formation under atmospheric conditions, Proc. Natl. Acad. Sci., 107, 6646-6651, doi:10.1073/pnas.0911330107, 2010.

Morawska, L., Ristovski, Z., Jayaratne, E. R., Keogh, D. U., and Ling, X.: Ambient nano and ultrafine particles from motor vehicle emissions: Characteristics, ambient processing and implications on human exposure, Atmos. Environ., 42, 8113-8138, 2008.

Napari, I., Noppel, M., Vehkamaki, H., and Kulmala, M.: An improved model for ternary nucleation of sulfuric acidammoniawater, J. Chem. Phys., 116, 4221-4227, 2002.

Nilsson, E. D. and M. Kulmala. The potential for atmospheric mixing processes to enhance the binary nucleation rate, J. Geophys Res., 103, 1381- 1389, 1998.

Nishita, C., K. Osada, M. Kido, K. Matsunaga, and Y. Iwasaka. Nucleation mode particles in upslope valley winds at Mount Norikura, Japan: Implications for the vertical extent of new particle formation events in the lower troposphere, J. Geophys. Res., 113, D06202, doi:10.1029/2007JD009302, 2008.

O'Dowd, C. D., Becker, E., and Kulmala, M.: Mid-latitude North Atlantic aerosol characteristics in clean and polluted air, Atmos. Res., 58, 167-185, 2001

O’Dowd, C. D., Yoon, Y. J., Junkermann, W., Aalto, P., Kulmala, M., Lihavainen, H., and Viisanen, Y.: Airborne measurements of nucleation mode particles II: boreal forest nucleation events, Atmos. Chem. Phys., 9, 937-944, doi:10.5194/acp-9-937-2009, 2009.

Olivares, G., Johansson, C., Strom, J., and Hansson, H. C.: The role of ambient temperature for particle number concentrations in a street canyon, Atmos. Environ., 41, 2145-2155, 2007.

Petäjä, T., Kerminen, V.-M., Dal Maso, M., Junninen, H., Koponen, I. K., Hussein, T., Aalto, P. P., Andronopoulos, S., Robin, D., Hämeri, K., Bartzis, J. G., and Kulmala, M.: Sub-micron atmospheric aerosols in the surroundings of Marseille and Athens: physical characterization and new particle formation, Atmos. Chem. Phys., 7, 2705-2720, doi:10.5194/acp-7-2705-2007, 2007

Peter, J. R., Siems, S. T., Jensen, J. B., Gras, J. L., Ishizaka, Y., and Hacker, J. M.: Airborne observations of the effect of a cold front on the aerosol particle size distribution and new particle formation, Q. J. Roy. Meteorol. Soc., 136, 944-961, 2010.

Pey, J., Rodriguez, S., Querol, X, Alastuey, A., Moreno, T., Putaud, J. P., and Van Dingenen, R.: Events and cycles of urban aerosols in the western Mediterranean, Atmos. Environ., 42, 9052-9062, 2008.

Pey, J., Querol, X., Alastuey, A., Rodríguez, S., Putaud, J. P., and Van Dingenen, R.: Source apportionment of urban fine and ultrafine particle number concentration in a Western Mediterranean city, Atmos. Environ., 43, 4407-4415, 2009. 
Pope, C. A., Burnett, R. T., Thun, M. J., Calle, E. E., Krewski, D., Ito, K., and Thurston, G. D.: Lung cancer, cardiopulmonary mortality, and long-term exposure to fine particulate air pollution, J. Am. Med. Assoc., 287, 1132-1141, 2002.

Pryor, S. C., Barthelmie, R. J., Sørensen, L. L., McGrath, J. G., Hopke, P., and Petäjä, T.: Spatial and vertical extent of nucleation events in the Midwestern USA: insights from the Nucleation In ForesTs (NIFTy) experiment, Atmos. Chem. Phys., 11, 16411657, doi:10.5194/acp-11-1641-2011, 2011.

Reche, C., Querol, X., Alastuey, A., Viana, M., Pey, J., Moreno, T., Rodríguez, S., González, Y., Fernández-Camacho, R., de la Rosa, J., Dall'Osto, M., Prévôt, A. S. H., Hueglin, C., Harrison, R. M., and Quincey, P.: New considerations for PM, Black Carbon and particle number concentration for air quality monitoring across different European cities, Atmos. Chem. Phys., 11, 6207-6227, doi:10.5194/acp-11-6207-2011, 2011.

Reddington, C. L., Carslaw, K. S., Spracklen, D. V., Frontoso, M. G., Collins, L., Merikanto, J., Minikin, A., Hamburger, T., Coe, H., Kulmala, M., Aalto, P., Flentje, H., Plass-Dülmer, C., Birmili, W., Wiedensohler, A., Wehner, B., Tuch, T., Sonntag, A., O’Dowd, C. D., Jennings, S. G., Dupuy, R., Baltensperger, U., Weingartner, E., Hansson, H.-C., Tunved, P., Laj, P., Sellegri, K., Boulon, J., Putaud, J.-P., Gruening, C., Swietlicki, E., Roldin, P., Henzing, J. S., Moerman, M., Mihalopoulos, N., Kouvarakis, G., Ždímal, V., Zíková, N., Marinoni, A., Bonasoni, P., and Duchi, R.: Primary versus secondary contributions to particle number concentrations in the European boundary layer, Atmos. Chem. Phys., 11, 12007-12036, doi:10.5194/acp-11-12007-2011, 2011

Riipinen, I., Pierce, J. R., Yli-Juuti, T., Nieminen, T., Häkkinen, S., Ehn, M., Junninen, H., Lehtipalo, K., Petäjä, T., Slowik, J., Chang, R., Shantz, N. C., Abbatt, J., Leaitch, W. R., Kerminen, V.-M., Worsnop, D. R., Pandis, S. N., Donahue, N. M., and Kulmala, M.: Organic condensation: a vital link connecting aerosol formation to cloud condensation nuclei (CCN) concentrations, Atmos. Chem. Phys., 11, 3865-3878, doi:10.5194/acp-11-38652011, 2011.

Rodriguez, S. and Cuevas, E.: The contributions of "minimum primary emissions" and "new particle formation enhancements" to the particle number concentration in urban air, J. Aerosol Sci., 38, 1207-1219, doi:10.1016/j.jaerosci.2007.09.001, 2007.

Salma, I., Borsós, T., Weidinger, T., Aalto, P., Hussein, T., Dal Maso, M., and Kulmala, M.: Production, growth and properties of ultrafine atmospheric aerosol particles in an urban environment, Atmos. Chem. Phys., 11, 1339-1353, doi:10.5194/acp-111339-2011, 2011.

Seaton, A., Godden, D., MacNee, W., and Donaldson, K.: Particulate air pollution and acute health effects, Lancet, 345, 176-178, 1995.

Siebert, H., Stratmann, F., and Wehner, B.: First observations of increased ultrafine particle number concentrations near the inversion of a continental planetary boundary layer and its relation to ground-based measurements, Geophys. Res. Lett., 31, L09102, doi:10.1029/2003GL019086, 2004.

Sipila, M., Berndt, T., Petaja, T., Brus, D., Vanhanen, J., Stratmann, F., Patokoski, J., Mauldin III, R. L., Hyvärinen, A.-P., Lihavainen, H., and Kulmala, M.: Role of Sulfuric Acid in Atmospheric Nucleation, Science, 327, 1243-1246, 2010.

Sogacheva, L., Hamed, A., Facchini, M. C., Kulmala, M., and Laaksonen, A.: Relation of air mass history to nucleation events in
Po Valley, Italy, using back trajectories analysis, Atmos. Chem. Phys., 7, 839-853, doi:10.5194/acp-7-839-2007, 2007.

Spracklen, D., Carslaw, K., Kulmala, M., Kerminen, V.-M., Sihto, S.-L., Riipinen, I., Merikanto, J., Mann, G., Chipperfield, M., Wiedensohler, A., Birmili, W., and Lihavainen, H.: Contribution of particle formation to global cloud condensation nuclei concentrations, Geophys. Res. Lett., 35, L06808, doi:10.1029/2007GL033038, 2008.

Spracklen, D. V., Carslaw, K. S., Merikanto, J., Mann, G. W., Reddington, C. L., Pickering, S., Ogren, J. A., Andrews, E., Baltensperger, U., Weingartner, E., Boy, M., Kulmala, M., Laakso, L., Lihavainen, H., Kivekäs, N., Komppula, M., Mihalopoulos, N., Kouvarakis, G., Jennings, S. G., O’Dowd, C., Birmili, W., Wiedensohler, A., Weller, R., Gras, J., Laj, P., Sellegri, K., Bonn, B., Krejci, R., Laaksonen, A., Hamed, A., Minikin, A., Harrison, R. M., Talbot, R., and Sun, J.: Explaining global surface aerosol number concentrations in terms of primary emissions and particle formation, Atmos. Chem. Phys., 10, 4775-4793, doi:10.5194/acp-10-4775-2010, 2010.

Stanier, C. O., Khlystov, A. Y., and Pandis, S. N.: Nucleation events during the Pittsburgh air quality study: Description and relation to key meteorological, gas phase and aerosol parameters, Aerosol Sci. Tech., 38, 253-264, 2004.

Tunved, P., Hansson, H.-C., Kerminen, V.-M., Ström, J., Dal Maso, M., Lihavainen, H., Viisanen, Y., Aalto, P. P., Komppula, M., and Kulmala, M.: High natural aerosol loading over boreal forests, Science, 312, 261-263, 2006.

Turpin, B. J. and Huntzicker, J. J.: Identification of secondary organic aerosol episodes and quantification of primary and secondary organic aerosol concentrations during SCAQS, Atmos. Environ., 29, 3527-3544, 1995.

Vakeva, M., Hameri, K., Kulmala, M., Lahdes, R., Ruuskanen, J., and Laitinen, T.: Street level versus rooftop concentrations of submicron aerosol particles and gaseous pollutants in an urban street canyon, Atmos. Environ., 33, 1385-1397, 1999.

Vana, M., Ehn, M., Petäjä, T., Vuollekoski, H., Aalto, P., de Leeuw, G., Ceburnis, D., O'Dowd, C. D., and Kulmala, M.: Characteristic features of air ions at Mace Head on the west coast of Ireland, Atmos. Res., 90, 278-286, 2008.

Velasco, E., Márquez, C., Bueno, E., Bernabé, R. M., Sánchez, A., Fentanes, O., Wöhrnschimmel, H., Cárdenas, B., Kamilla, A., Wakamatsu, S., and Molina, L. T.: Vertical distribution of ozone and VOCs in the low boundary layer of Mexico City, Atmos. Chem. Phys., 8, 3061-3079, doi:10.5194/acp-8-3061-2008, 2008.

Vehkamaki, H., Kulmala, M., Lehtinen, K., Timmreck, C., Noppel, M., and Laaksonen, A.: An Improved Parameterization for Sulfuric Acid-water Nucleation Rates for Tropospheric and Stratospheric Conditions, J. Geophys. Res., 107, 4622, doi:10.1029/2002JD002184, 2002.

Wehner, B., Siebert, H., Stratmann, F., Tuch, T., Wiedensohler, A., Petäjä, T., Dal Maso, M., and Kulmala, M.: Horizontal homogeneity and vertical extent of new particle formation events, Tellus B, 59, 362-371, 2007.

Wehner, B., Siebert, H., Ansmann, A., Ditas, F., Seifert, P., Stratmann, F., Wiedensohler, A., Apituley, A., Shaw, R. A., Manninen, H. E., and Kulmala, M.: Observations of turbulence-induced new particle formation in the residual layer, Atmos. Chem. Phys., 10, 4319-4330, doi:10.5194/acp-10-4319-2010, 2010. 
Zhang, K. M., Wexler, A. S., Zhu, Y. F., Hinds, W. C., and Sioutas, C.: Evolution of particle number distribution near roadways. Part II. The road-to-ambient processes, Atmos. Environ., 38, 66555556,2004
Zhu, Y., Hinds, W. C., Kim, S., Shen, S., and Sioutas, C.: Study of ultrafine particles near a major highway with heavy-duty diesel traffic, Atmos. Environ., 36, 4323-4335, 2002. 